\title{
Expedition 333 summary ${ }^{1}$
}

\author{
Expedition 333 Scientists $^{2}$
}

\section{Chapter contents}

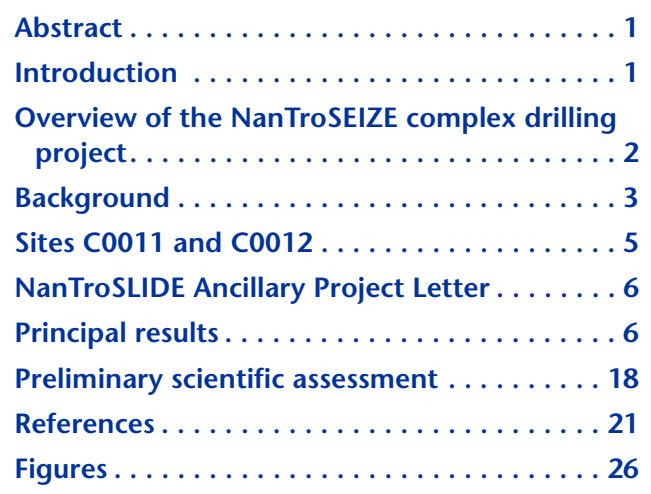

${ }^{1}$ Expedition 333 Scientists, 2012. Expedition 333 summary. In Henry, P., Kanamatsu, T., Moe, K., and the Expedition 333 Scientists, Proc. IODP, 333: Tokyo (Integrated Ocean Drilling Program Management International, Inc.). doi:10.2204/iodp.proc.333.101.2012 'Expedition 333 Scientists' addresses.

\section{Abstract}

The Nankai Trough Seismogenic Zone Experiment (NanTroSEIZE) program is a coordinated, multiexpedition drilling project designed to investigate fault mechanics and seismogenesis along subduction megathrusts through direct sampling, in situ measurements, and long-term monitoring in conjunction with allied laboratory and numerical modeling studies. Some of the fundamental scientific objectives of the NanTroSEIZE drilling project include characterizing the nature of fault slip and strain accumulation, fault and wall rock composition, fault architecture, and state variables throughout the active plate boundary system to a depth of $7000 \mathrm{~m}$ below seafloor. It is also important to show how such properties evolve from shallow, presubduction conditions in the Shikoku Basin to greater depths of the accretionary prism where fault slip is seismogenic. Within this context, the primary goals for Integrated Ocean Drilling Program (IODP) Expedition 333 were (1) drilling and coring of previously unsampled intervals of sediment and basalt at IODP Sites C0011 and C0012 in the Shikoku Basin, together with downhole measurements of temperature, and (2) drilling and coring at a site near the updip terminus of the megasplay fault, as proposed in an Ancillary Project Letter (738-APL: Nankai Trough Submarine Landslide History [NanTroSLIDE]).

The most important accomplishments were (1) determination of heat flow at Sites C0011 and C0012, (2) coring through a transition in physical properties within the upper part of the Shikoku Basin hemipelagic sediments, (3) repeated coring and sampling of fluid above the sediment/basement interface for shore-based geochemical studies, (4) coring into the basalt to $100 \mathrm{~m}$ below the sediment/basalt interface, and (5) drilling and sampling a nearly complete slope basin stratigraphic succession comprising six mass transport deposits that record $\sim 1$ m.y. submarine landsliding history near the shallow megasplay fault zone area.

\section{Introduction}

The Center for Deep Earth Exploration (CDEX) accomplished three Nankai Trough Seismogenic Zone Experiment (NanTroSEIZE) expeditions during 2010 and early 2011: Integrated Ocean Drilling Program (IODP) Expedition 326 (NanTroSEIZE Stage 3: plate boundary deep riser: top hole engineering), Expedition 332 
(NanTroSEIZE Stage 2: riserless observatory), and Expedition 333 (NanTroSEIZE Stage 2: subduction inputs 2 and heat flow).

The objectives for Expedition 333 were to core and measure temperature within the shallow intervals at IODP Sites C0011 and C0012 that were not adequately sampled during IODP Expedition 322 and to collect up to $220 \mathrm{~m}$ of additional basement material from Site C0012 (Fig. F1). These are the two subduction inputs sites for the Kumano transect, positioned above and on the northwest flank of a prominent basement high in the Shikoku Basin. Additionally, the coring objectives of an Ancillary Project Letter (738-APL), Nankai Trough Submarine Landslide History (NanTroSLIDE), were attempted to correlate the history of submarine landslides along the lower forearc slope to the history of slip along the megasplay fault.

\section{Overview of the NanTroSEIZE complex drilling project}

Subduction zones account for $90 \%$ of global seismic moment release, generating damaging earthquakes and tsunamis with potential disastrous effects on heavily populated areas (e.g., Lay et al., 2005). Understanding the processes that govern the strength, nature, and distribution of slip along these plate boundary fault systems is crucial for evaluating earthquake and tsunami hazards. Sediment-dominated subduction zones such as the Eastern Aleutian, Cascadia, Sumatra, and Nankai margins are characterized by repeated great earthquakes of magnitude M 8.0+ (Ruff and Kanamori, 1983). Although the causative mechanisms are not well understood (e.g., Byrne et al., 1988; Moore and Saffer, 2001; Saffer and Marone, 2003), the updip limit of the seismogenic zones at these margins is thought to correlate with a topographic break, often associated with the outer rise of the forearc (e.g., Byrne et al., 1988; Wang and $\mathrm{Hu}$, 2006). At Nankai, seismic reflection profiles across the forearc outer rise document an out-of-sequence thrust (OOST) fault system (the megasplay fault) that branches from the plate boundary décollement close to the updip limit of inferred coseismic rupture of the 1944 Tonankai M 8.2 earthquake (Moore et al., 2007) (Fig. F2).

The NanTroSEIZE project is a complex drilling project (CDP): a multiexpedition, multistage component of IODP focused on understanding the mechanics of seismogenics and rupture propagation along subduction plate boundary faults. NanTroSEIZE is a coordinated effort to sample and instrument the plate boundary system at several locations offshore the Kii
Peninsula, Japan (Tobin and Kinoshita, 2006b). The main objectives are to understand

- The mechanisms and properties governing the updip aseismic-seismic transition of the megathrust and plate interface fault systems;

- Processes of earthquake and tsunami generation, as well as strain accumulation and release; and

- The mechanical strength and hydrogeologic behavior of the plate boundary fault and megasplay.

The following hypotheses are paraphrased from the original IODP proposals and outlined in Tobin and Kinoshita (2006a, 2006b):

1. Systematic, progressive material and state changes control the onset of seismogenic behavior on subduction thrust faults.

2. Subduction megathrusts are weak faults.

3. Plate motion is accommodated primarily by coseismic slip in a concentrated zone (i.e., the fault is locked during the interseismic period).

4. Physical properties of the plate boundary system (including the fault system and its hanging wall and footwall) change with time during the earthquake cycle.

5. A significant, laterally extensive upper plate fault system (the megasplay) slips in discrete events that may include tsunamigenic slip during great earthquakes. It remains locked during the interseismic period and accumulates strain.

To address Hypothesis 1 above, it is essential to document the composition and geotechnical/frictional/ hydrogeological properties of the subduction inputs (i.e., the initial conditions) before the igneous rocks and sedimentary strata reach the deformation front and begin to change. As stated in Hypothesis 5 above, two of the first-order goals in characterizing the seismogenic zone along the Nankai Trough are to document the role of the megasplay fault in accommodating plate motion (both seismically and interseismically) and to characterize the fault's mechanical and hydrological behavior. This research bears on understanding both fault behavior and tsunami hazards.

Presently, the NanTroSEIZE CDP encompasses 12 sites along a transect that extends from the northwest edge of the Shikoku Basin across the frontal thrust region, the midslope megasplay region, and into the Kumano Basin forearc region (Figs. F1, F2). One of these sites (IODP Site C0002) currently includes a pilot hole for the planned deep riser drilling operations. The other sites targeted fault zones in the shallow, aseismic portions of the accretionary complex (Kinoshita, Tobin, Ashi, Kimura, Lallemant, Screaton, Curewitz, Masago, Moe, and the Expedi- 
tion $314 / 315 / 316$ Scientists, 2009) and the subduction inputs (Underwood et al., 2010).

From late 2007 through early 2008, IODP Expeditions 314,315 , and 316 were carried out as a unified program known as NanTroSEIZE Stage 1. Expedition 314 was dedicated to downhole measurement of physical properties and borehole imaging through logging while drilling (LWD). Expedition 315 was devoted to core sampling and downhole temperature measurement at two sites in the hanging wall: IODP Site C0001 just seaward of the outer rise and Site C0002 in the Kumano Basin. Expedition 316 targeted the frontal thrust region and megasplay in their shallow aseismic portions: IODP Site C0004 near the surface expression of the megasplay in the Kumano Basin, IODP Sites C0006 and C0007 at the frontal thrust of the accretionary wedge, and IODP Site C0008 in a trench-slope basin seaward of the splay fault. For more details, see Kinoshita, Tobin, Ashi, Kimura, Lallemant, Screaton, Curewitz, Masago, Moe, and the Expedition 314/315/316 Scientists (2009).

IODP Expeditions 319 and 322 followed in 2009, as NanTroSEIZE Stage 2. Expedition 319 prepared boreholes at IODP Sites C0009 and C0010 for future installation of long-term monitoring systems. At Site C0009, Expedition 319 also conducted the first riser operation in IODP history, as well as a walkaway vertical seismic profile experiment (Saffer, McNeill, Byrne, Araki, Toczko, Eguchi, Takahashi, and the Expedition 319 Scientists, 2010). Expedition 322 cored Sites C0011 and C0012 in the Shikoku Basin to document the composition and material properties of sediment and uppermost igneous basement that eventually enters the Nankai subduction zone (Underwood et al., 2010). Expedition 332 in 2011 further succeeded by placing a new monitoring system at Site C0010 after retrieving data over a 15 month period and installing a permanent observatory system at Site C0002 (Kopf et al., 2011).

\section{Background Geological setting}

The Nankai Trough is a convergent plate boundary where the Philippine Sea plate underthrusts the southwestern Japan margin. At the Kumano transect across the Nankai Trough, the velocity between the Philippine Sea plate and the forearc is $4.5-5.5 \mathrm{~cm} / \mathrm{y}$ along an azimuth of $305^{\circ} \pm 3^{\circ}$ (Fig. F1) (Seno et al., 1993; Mazzotti et al., 2000; DeMets et al., 2010; Loveless and Meade, 2010]) down an interface dipping $3^{\circ}-7^{\circ}$ (Kodaira et al., 2000a). Uncertainty on the velocity is primarily related to uncertainty on the amount of right-lateral motion accommodated by shear partitioning on the median tectonic line and offshore faults. The subducting lithosphere of the Shikoku Basin was formed by backarc spreading during a time period of approximately 15-25 Ma (Okino et al., 1994).

The three major seismic stratigraphic sequences identified in the northern Shikoku Basin are the lower and upper Shikoku Basin facies and local spillover of Quaternary trench-wedge turbidites (Ike et al., 2008b). The upper Shikoku Basin seismic unit off the Kumano Basin transect area thins toward the north, whereas the lower seismic succession has a more complicated isopach geometry strongly influenced by basement topography (Le Pichon et al., 1987a, 1987b; Mazzotti et al., 2002; Moore, Taira, Klaus, et al., 2001; Moore et al., 2001; Ike et al., 2008b). Throughout the basin, seismic thickness decreases above large basement highs and the inferred sand-rich packages of the lower Shikoku Basin pinch out against or lap onto basement highs. Basement highs are imaged within the subduction zone (Kodaira et al., 2003, Dessa et al., 2004) where they influence margin structure (Lallemand et al., 1992; Le Pichon et al., 1996; Park et al., 1999; Mazzotti et al., 2002; Bangs et al., 2006; Moore et al., 2009) and seismicity (Kodaira et al., 2000b; Park et al., 2004). The mechanical and hydrogeological differences between strata above subducting basement highs and regions with smooth basement topography could be significant for modulating fault zone dynamics and earthquake rupture behavior.

The lower forearc slope of the Nankai Trough consists of a series of thrust faults that have shortened the accreted sedimentary units of the prism (e.g., Moore et al., 2009; Screaton et al., 2009). Swath bathymetry and multichannel seismic (MCS) data show a pronounced and continuous outer arc high extending $>120 \mathrm{~km}$ along strike, which may be related to slip on the megasplay fault (Moore et al., 2009; Martin et al., 2010). The outer arc high coincides with the updip end of the splaying system of thrust faults that branch from a strong seismic reflector interpreted by Park et al. (2002) as a major OOST. The megasplay fault is hypothesized to represent the mechanical boundary between the inner and outer accretionary wedge and between aseismic and seismogenic fault behavior (Wang and $\mathrm{Hu}, 2006$ ). At depth, this megasplay produces a high-amplitude reflector (Fig. F2). It branches into a family of thrust splays in the upper few kilometers below the seafloor, including the thrust splay drilled during Stage 1 Expeditions 314, 315, and 316 (Moore et al., 2007, 2009).

The plate boundary, when traced in the downdip direction on seismic profiles, eventually ramps down 
from a sediment/sediment interface to the sediment/ basalt or an intrabasalt interface (Park et al., 2002). This shift in lithologic position of the fault must coincide with fundamental changes in the rock's mechanical and/or hydrologic properties, but how so? Shore-based studies indicate that systematic fragmentation of upper basement and incorporation of basalt slabs into shear-zone mélanges could be controlled by primary layering of the igneous rock (Kimura and Ludden, 1995). By coring additional basement rocks seaward of the trench, we hope to discriminate between the presubduction features in basement inherited from backarc spreading in the Shikoku Basin and the changes imparted by increasing pressure-temperature (P-T) conditions and stress at depth (documented in the future by deep riser drilling).

\section{Previous drilling achievements Sites C0011 and C0012}

Expedition 322 was designed to document characteristics of incoming sedimentary strata and uppermost igneous basement prior to their arrival at the subduction front (Saito et al., 2009). To accomplish those objectives, coring was conducted at two sites on the subducting Philippine Sea plate. Site C0011 is located on the northwest flank of a prominent bathymetric high (the Kashinosaki Knoll; Ike et al., 2008a), whereas Site C0012 is located near the crest of the knoll (Fig. F2).

The resulting data, which include LWD at Site C0011 during Expedition 319, provide a great deal of new information on presubduction equivalents of the seismogenic zone (Underwood et al., 2010). Core samples at Site C0011 were obtained by rotary core barrel (RCB) drilling from 340 to 876 meters below seafloor (mbsf) where the hole was abandoned because of failure of the drill bit. After jetting-in to $\sim 70$ mbsf, RCB coring at Site C0012 penetrated almost $23 \mathrm{~m}$ into igneous basement and recovered the sediment/basalt interface intact at 537.81 mbsf. This incomplete coring program left major gaps in the stratigraphic coverage, particularly within intervals of the upper Shikoku Basin. Core quality and core recovery were also poor, which compromised the scientific outcomes. Nevertheless, the merger of lithofacies and age-depth models shows how correlative units change from an expanded section at Site C0011 to a condensed section at Site C0012. The composite section also captures most of the important ingredients of basin evolution, including a previously unrecognized interval of late Miocene volcaniclastic sandstone designated by Expedition 322 Scientists as the middle Shikoku Basin facies. An older (early-middle Miocene) turbidite sandstone/ siltstone facies with mixed volcaniclastic-siliciclastic detrital provenance occurs in the lower Shikoku Basin; this unit may be broadly correlative with superficially similar Miocene turbidites on the western side of the basin (Underwood, 2007). The age of basal sediment (reddish-brown pelagic claystone) at Site C0012 is older than 18.9 Ma.

Geochemical analyses of interstitial water on top of the basement high show clear evidence of upward diffusion of sulfate and other dissolved chemical species from the basement (Underwood et al., 2010). The depth of the sulfate reduction zone is also anomalously deep at Site C0012. Chlorinity values increase toward basement because of hydration reactions in the sediment and diffusional exchange with basement fluids. In contrast to Site C0011, where chlorinity decreases with depth, the more saline fluids at Site C0012 are largely unchanged by the effects of focused flow and/or in situ dehydration reactions associated with rapid burial beneath the trench wedge and frontal accretionary prism. Thus, Site C0012 finally provides a reliable geochemical reference site, unaffected by subduction processes.

\section{Seismic studies/site survey data}

Site survey data have been collected in the drilling area over many years, including multiple generations of 2-D seismic reflection (e.g., Park et al., 2002), wide-angle refraction (Nakanishi et al., 2002), passive seismicity (e.g., Obana et al., 2004; Obara and Ito, 2005; Ito and Obara, 2006), heat flow (Yamano et al., 2003), side-scan sonar, swath bathymetry, and visual observations from submersible and remotely operated vehicle dives (Ashi et al., 2002). In 2006, Japan and the United States conducted a joint 3-D seismic reflection survey over a $\sim 11 \mathrm{~km} \times 55 \mathrm{~km}$ area, acquired by PGS Geophysical, an industry service company (Moore et al., 2007). This 3-D data volume was used to refine selection of drill sites and targets in the complicated megasplay fault region, define the regional structure and seismic stratigraphy, analyze physical properties of the subsurface through seismic attribute studies in order to extend information away from boreholes, and assess drilling safety (Moore et al., 2009). A smaller 3-D survey was conducted over proposed Sites NT1-01A (C0012) and NT1-07A (C0011) in 2006 by the Japan Agency for Marine-Earth Science and Technology-Institute for Research on Earth Evolution (JAMSTEC-IFREE) (Park et al., 2008). Prestack depth migration of those data led to refined velocity models and revised estimates of sediment thickness and total drilling depths. 


\section{Sites C0011 and C0012}

\section{Scientific objectives}

As mentioned previously, the upper stratigraphic intervals of the Shikoku Basin facies were not adequately sampled during Expedition 322. Therefore, one of the priorities for Expedition 333 was to fill in the coring gaps and expand the age-depth models into the Pliocene and Quaternary. The shallow section is also important for comprehensive profiles of physical properties and organic and interstitial water geochemistry. Thermal structure, including the effects of fluid circulation in the basement, is another of the critical input variables to document because of its influence on sediment diagenesis and fluid chemistry (Spinelli and Underwood, 2005; Saffer and McKiernan, 2009; Spinelli and Wang, 2008). The age of subducting lithosphere within the Kumano transect area is $\sim 20 \mathrm{Ma}$ (Okino et al., 1994), as verified by coring at Site C0012 (Underwood et al., 2010). The Kashinosaki Knoll lies west of the Zenisu Ridge intraoceanic thrust, which brings backarc basin crust to crop out at the seafloor further to the east (Lallemant et al., 1989; Henry et al., 1997). However, the respective contributions of active compressive tectonics and seamount volcanism to the Kashinosaki Knoll morphology are unclear, and the exact timing of volcanic activity responsible for the birth of the Kashinosaki Knoll (Ike et al., 2008a) still needs to be established by radiometric dating of the basalt. Dense near-surface heat flow measurements around the Kashinosaki Knoll indicate significantly higher value than the theoretical value estimated from the age of the Shikoku Basin (Kinoshita et al., 2008). Deeper thermal structure is required to document the entire heat flow pattern around the sites with high-quality borehole temperature measurement.

As subduction carries Shikoku Basin strata toward and beneath the accretionary prism, we expect fluids and physical properties to change downsection and downdip in response to hydration reactions (e.g., volcanic glass to zeolite + smectite), dehydration reactions (e.g., opal-to-quartz and smectite-to-illite), and crystalline cement precipitation (carbonates, zeolites, and silica). Documenting such changes is an essential ingredient of the NanTroSEIZE science plan. Sharp diagenetic fronts (especially opal-to-quartz) have been linked to anomalous offsets in profiles of porosity, $P$-wave velocity, and other geotechnical properties (Spinelli et al., 2007). LWD data from Site C0011 show offsets at $250 \mathrm{~m}$ LWD depth below seafloor (LSF) that may be caused by this type of reaction (Underwood et al., 2010). Alteration of dis- persed volcanic glass is also potentially important during diagenesis but, as yet, this component of the sediment budget is poorly understood (Scudder et al., 2009). Similarly, hydrous authigenic phases in the basalt (e.g., saponite from ridge-flank hydrothermal alteration) are susceptible to diagenetic reactions at higher temperatures. Updip migration of fluids (including hydrocarbons) toward the Shikoku Basin from landward zones of deeper seated dehydration reactions is a distinct possibility (Saffer et al., 2008), and this idea can be tested through a comprehensive program of geochemical analyses. Interpretation of the geochemistry, however, requires constraints on the in situ temperature.

Characterization of basement composition and structure is a high priority for NanTroSEIZE. Permeability and fluid flow within oceanic basalt are affected by many variables (Fisher, 1998). A long-term goal is to monitor and sample fluids in the basement using subseafloor observatories, but design of those experiments hinges on coring and logging results. As a prelude, we planned to concentrate first on documenting the basement's structural architecture, hydrologic properties, and early alteration products. Products of early alteration within the uppermost basalt (e.g., saponite and calcite) change the rock's bulk chemistry and physical properties (porosity and permeability). The extent of this alteration is important for constraining the volatile content of subducting crust. In addition, coring at least $100 \mathrm{~m}$ into basement and wireline logging during a future expedition will capture heterogeneities in fracture patterns and porosity that might be involved in delamination of the basalt downdip in the seismogenic zone.

The specific set of questions addressed by additional drilling at input sites are

- Is fluid circulation in basement and permeable sedimentary layers influencing heat flow and diagenesis at Sites C0011 and C0012?

- How does contrasting interstitial fluid chemistry at Sites C0011 and C0012 relate with in situ diagenesis and fluid flow?

- Can a change of physical properties between 200 and 250 mbsf at Site C0011 be related to lithologic variation or silica diagenesis? Does the same transition occur at Site C0012?

- Was magmatic activity heterogeneous in composition and age on the backarc basin basement high (Kashinosaki Knoll)?

- Is alteration of the upper oceanic basement heterogeneous and how does such alteration influence geochemical and fluid budgets? 


\section{NanTroSLIDE Ancillary Project Letter}

\section{Scientific objectives}

Expedition 333 drilled and sampled the slope basin seaward of the megasplay that is characterized in 3-D seismic data by stacked mass transport deposits (MTDs) (Strasser et al., 2011) (Fig. F3). The aim of the coring was to establish the submarine landslide history and reconstruct transport dynamics. Core from IODP Site C0018 (proposed Site NTS-1A) was to be integrated with 3-D seismic interpretation and data from nearby NanTroSEIZE sites to determine the relation of submarine landslides to tectonic evolution. By establishing a better physical understanding of tectonic processes and slope failures, we planned to also gain a general understanding of failure-related sedimentation patterns and the significance of episodic mass transport events. Ultimately, this could help us assess the tsunamigenic potential of tectonic landslides. The primary goals of drilling Site C0018 were

1. To establish a well-dated Quaternary massmovement event stratigraphy and

2. To sample the distal part of an exceptionally thick MTD for analyzing its rheological behavior to constrain sliding dynamics and tsunamigenic potential.

These aim at providing answers to the following questions:

1. What is the frequency of submarine landslides?

2. What is the source materials of the MTDs?

3. What is the importance of accretionary wedge remobilization versus surficial processes?

4. What controls type, size, and magnitude of turbitides and MTDs and how do they change through time?

5. How do large MTDs relate to the timing of splay fault activity as inferred from NanTroSEIZE Stage 1 drilling (Strasser et al., 2009)?

6. What are the dynamics of large submarine landslides and can we infer their tsunamigenic potential?

By addressing these questions, we aimed to isolate tectonic processes influencing magnitude and occurrence of submarine landslides along active subduction zone margins and to understand their potential for triggering catastrophic events in terms of both hazards (tsunamigenic landslides) and sediment mass transfer within the context of margin evolution.

\section{Drilling strategy}

Site C0018 (water depth $=3100 \mathrm{~m}$ ) is located on a margin-perpendicular transect $4.5 \mathrm{~km}$ southwest of the NanTroSEIZE Stage 1 drilling transect (Fig. F1). It is located $5 \mathrm{~km}$ south-southwest of Site C0008, which was drilled into a small slope basin seaward of the megasplay fault (Kinoshita, Tobin, Ashi, Kimura, Lallemant, Screaton, Curewitz, Masago, Moe, and the Expedition 314/315/316 Scientists, 2009). Site C0008 results show the utility of using the ages of MTDs to reconstruct slope failure activity related to megasplay fault movements (Strasser et al., 2009, 2011). Apart from the deepest section, Site C0008 lacks clear evidence for MTDs because of a significant hiatus in its upper part, suggesting erosion related to a prominent slope collapse structure seaward of the megasplay fault (Strasser et al., 2011; Conin et al., 2011). On the basis of new 3-D seismic data interpretation, the Ancillary Project Letter proponents have identified a lower slope basin that (1) better represents the depocenter for downslope mass transport, (2) is clearly characterized by stacked MTDs as seismically imaged by acoustically transparent to chaotic bodies with ponded geometries (Fig. F3), and (3) includes a large, as thick as $182 \mathrm{~m}$, MTD (Strasser et al., 2011). Expedition 333 drilled at a location where the MTD bodies wedge out and where basal erosion is minimal. Continuous coring with the hydraulic piston coring system (HPCS) and the extended shoe coring system (ESCS)/extended punch coring system (EPCS) to $\sim 315$ mbsf allowed sampling of the MTDs across the most complete and longest stratigraphic succession.

\section{Principal results} Site $\mathrm{C0018}$

The primary goals of drilling Site C0018 were to establish a well-dated Quaternary mass-movement event stratigraphy and to sample the distal part of an exceptionally thick MTD for analyzing its rheological behavior to constrain sliding dynamics and tsunamigenic potential (Fig. F3). Identification of MTD intervals in cores relied on a combination of observations:

- Indications for sediment remobilization and internal deformation during mass transport: Evidence for sediment remobilization includes convolute strata, chaotic and brecciated facies, mud pebbles, absence of bioturbation, and mixed sediments of different grain sizes. Deformation styles can be highly variable, and parts that only experienced 
moderate plastic deformation concentrated to restricted zones may contain intervals of coherently bedded sediments. Dipping beds, small folds, and faults are common occurrences in these parts. However, assessment of bedding dips and fault orientation is needed to distinguish deformation attributable to slope instability from postdepositional tectonic deformation, which could result from strain in the underlying accretionary wedge. Paleomagnetism (i.e., for HPCS coring: dispersed paleomagnetic declination and inclination) can provide additional arguments to recognize zones of sediment perturbation, notably in the absence of bedding. Contrasts of physical properties and physical composition may also help define the boundaries between intact and remobilized sediments.

- Upper boundary/contact: The upper contact surface of MTDs may be identified from the presence of a boundary between undisturbed subhorizontal and bioturbated sediment above and disturbed sediments below, without evidence for shearing. A turbidite, originating from erosion resulting from viscous drag of the frontal part of the moving mass, as has been shown experimentally, could be a marker associated with the larger events (Lee et al., 2004; Solheim et al., 2005).

- Lower boundary/contact of MTDs: The lower contact may appear as an erosional boundary between flowed and/or sheared sediments above and flatlying sediments below. However, deformation could also occur in the underlying sediments as a consequence of shear during flow and/or postdepositional loading (e.g., Schnellmann et al., 2005; Frey-Martínez et al., 2006; Alves and Lourenço, 2010). The lower contact may also appear as subhorizontal shear zone. A shear zone in the context of the Nankai accretionary wedge can be of tectonic origin, and, when related to gravity sliding, is not necessarily tied to a single event. Multiple shear zones can also result from nonuniform strain distribution within the MTD. However, structural relationships and stratigraphy may lead to propose a shear zone as forming the base of an MTD.

- Biostratigraphy and chronology: Age constraints, as inferred from biostratigraphy, magnetostratigraphy, tephrostratigraphy, and (postcruise) isotope stratigraphy, can resolve conformable MTD-overlying and MTD-underlying strata and/or age gaps, as well as the possible admixture of older nannofossil and/or plankton assemblages within MTDs. The age of the hemipelagic/pelagic sediments deposited immediately above the MTD can define the minimum age of the underlying landslide, considering the slide as one single, discrete event. The base of a MTD may, however, have a different significance depending on where observations are performed. In the distal downslope part of the MTD, the base may represent a depositional surface, on which the remobilized material ceased downslope movement. In this case, the sediment immediately below the MTD can, in principle, have a similar or only slightly older age as strata immediately above. In more proximal parts, however, basal erosion is likely a frequent process that can result in a hiatus. In the source region, the base of the slide is presumably a zone of concentrated shear that may not necessarily be described as a stratigraphic contact.

\section{Overview}

Slope sediments cored in Hole C0018A are divided into two lithologic subunits. Lithologic Subunit IA is primarily composed of hemipelagic mud (i.e., silty clay) with interbedded volcanic ash layers and is affected by MTDs (Fig. F4). Lithologic Subunit IB is a sandy turbidite sequence. Two thick ash layers were tentatively correlated on the basis of characteristic microscopic features observed in smear slides with onland tephra deposits (Azuki and Pink) that originated from Kyushu volcanoes (Hayashida et al., 1996). The Pink ash layer, dated on land as $1.05 \mathrm{Ma}$, lies at 183.8-190.65 mbsf, close the base of Subunit IA and the base of the thick MTD. The Azuki ash layer, dated on land as $0.85 \mathrm{Ma}$, is found at 125.65$126.45 \mathrm{mbsf},<1 \mathrm{~m}$ above the top of the thick MTD. These correlative ages were used to constrain magnetostratigraphy and are compatible with preliminary micropaleontological data.

Six intervals with evidence for MTDs are observed within Subunit IA and numbered from top to bottom for convenience (Fig. F4). The upper boundary/ contact is well defined for MTDs 1, 2, and 6 and is marked by a turbidite for two of them (MTDs 2 and 6) (Fig. F6 in the "Site C0018" chapter [Expedition 333 Scientists, 2012d]). MTD 1 extends over $2.9 \mathrm{~m}$ of chaotic and convolute bedding in Core 333-C0018A1H. MTD 2 comprises in its lower part several intervals of coherent bedding limited by probable shear zones. The lowermost one defines the base of the MTD 2 interval (Fig. F7 in the "Site C0018" chapter [Expedition 333 Scientists, 2012d]). MTD 3 comprises an interval with visual evidence for remobilization near its top, and examination of X-ray computed tomography (CT) scan and structural data lead to considering this interval as part of a thicker MTD zone. MTD 4 is a relatively thin interval $(50 \mathrm{~cm})$ associated with a fluidized ash layer (Fig. F8 in the "Site C0018" chapter [Expedition 333 Scientists, 
2012d]). MTD 5 extends over cores that were also disturbed by the coring process. A zone of remobilization is identified based on visual evidence and CT scan in Core 333-C0018A-9H, although this core was damaged during extraction from the core barrel. Evidence for a shear zone with a sharp lower boundary on X-ray CT scan images defines the base of MTD 5; however, it is yet unclear whether this MTD interval corresponds to a single event deposit. MTD 6 is a $61 \mathrm{~m}$ interval between 127.55 and $188.57 \mathrm{mbsf}$ and corresponds to the main MTD body identified in the seismic data by Strasser et al. (2011). As already noted, a turbidite deposit is found immediately above its upper boundary. Chaotic and convolute bedding (Fig. F9 in the "Site C0018" chapter [Expedition 333 Scientists, 2012d]) and mixing of ash with hemipelagite deposits are observed in the cores, but other intervals remain coherently bedded. Several shear zones are identified from CT scans in the lower part of MTD 6, but none could be positively identified as the basal surface. The base of the thick MTD was thus defined at the top of the Pink ash layer.

Important findings are a correlation of MTD occurrence with a change in sedimentation from turbidite to hemipelagite dominated and the presence of a thick ash layer at or near the base of the thick MTD. Whereas the presence of a thick ash layer at, or near, the lithologic boundary is likely coincidental, the peculiar stratigraphic context of the thick MTD suggests that sediment properties, and their variations, have a major influence on MTD occurrence and size.

\section{Lithology}

Hole C0018A was entirely drilled in a slope basin stratigraphic succession. Slope deposits overlying the accretionary wedge were defined as lithologic Unit I in previous expedition reports. In Hole C0018A, a marked difference was observed in cores between a dominantly hemipelagic section bearing ash layers, volcaniclastic sands, occasional siliclastic turbidites and intercalated MTDs forming Subunit IA (above $190.65 \mathrm{mbsf})$, and a sequence of sandy turbidites forming Subunit IB and interpreted as a sand-rich slope basin (Fig. F10 in the "Site C0018" chapter [Expedition 333 Scientists, 2012d]). These subunits correlate with seismic Units $1 \mathrm{a}$ and $1 \mathrm{~b}$ of Kimura et al. (2011) and Strasser et al. (2011). Within Subunit IA, the interval between 24.04 and 57.51 mbsf contains more abundant silty and sandy turbidites than intervals above and below. Three facies (IAi, IAii, and IAiii) are thus defined within Subunit IA. Turbidites in Facies IAii are dominantly of volcaniclastic origin. Conversely, samples with relatively higher plagioclase content, lower quartz content, and higher clay content in Facies IAii reflect an altered ash compo- nent (Fig. F5 in the "Site C0018" chapter [Expedition 333 Scientists, 2012d]). Sequences of thin $(\sim 5 \mathrm{~cm})$, silty to very fine sand turbidites are also found above ash layers in the lower part of Facies IAiii. Sands in Subunit IB have a mixed composition with quartz, plagioclase, and abundant lithic fragments of both metamorphic and volcanic origin, and thus are not considered to be volcaniclastic sands. An increase in quartz content and in the variability of mineral composition from Subunits IA to IB is observed in the Xray diffraction (XRD) data (Fig. F5 in the "Site C0018" chapter [Expedition 333 Scientists, 2012d]). Below 190.65 mbsf there is also a marked decrease in the relative abundance of nannofossils, diatoms, and spicules. Calcite content from bulk powder XRD, calcium content from X-ray fluorescence (XRF) (Fig. F11 in the "Site C0018" chapter [Expedition 333 Scientists, 2012d]), and carbonate content from coulometric analysis are consistently higher in Subunit IA than in Subunit IB and tend to increase uphole within Subunit IA.

Two remarkably coarse-grained ash layers occur within Unit I and are attributed to cataclysmic eruptions in Kyushu, known from widespread tephra deposits on land. A normally coarse (sand-sized) ash 80 $\mathrm{cm}$ thick is found at 125.65-126.45 mbsf and interpreted as the Azuki event, dated on land as $0.85 \mathrm{Ma}$ (Hayashida et al., 1996) (Fig. F8 in the "Site C0018" chapter [Expedition 333 Scientists, 2012d]). A dark sand-sized to fine ash layer, which was fluidized upon coring, is found at 183.8-190.65 mbsf. Our provisional correlation is with the Pink event, dated on land as 1.05 Ma (Hayashida et al., 1996) (Fig. F8 in the "Site C0018" chapter [Expedition 333 Scientists, 2012d]). These preliminary correlations are based on visual observations of the shape of the glass shards and dominant associated minerals in smear slides. The Subunit IA/IB boundary lies below this ash layer.

\section{Structural geology}

Structural features of Site C0018 mainly record gravity-driven deformation and mass-movement processes. The main structural features from visual core description at this site are subhorizontal and southeast-dipping beds and northward- and southwarddipping normal faults, outside MTD intervals in the upper part of the borehole (0-127.26 mbsf); scattered bedding dips, fault zones, and flow structures within the thick MTD (127.55-188.57 mbsf); and subhorizontal beds and fissility below the thick MTD (188.62-313.655 mbsf) (Fig. F12 in the "Site C0018" chapter [Expedition 333 Scientists, 2012d] and Fig. F5). A remarkable overturned fold was also observed within MTD 2 at 41.2 mbsf (Fig. F16 in the "Site 
C0018" chapter [Expedition 333 Scientists, 2012d]). CT scans may provide additional evidence for shearing. Lines with very high CT values (3000 or more) were identified as early diagenetic pyrite, which may constitute a marker of ductile deformation. Furthermore, small faults and thin shear bands $(<3 \mathrm{~mm})$ associated with MTDs appear generally denser on CT scan images (Fig. F18 in the "Site C0018" chapter [Expedition 333 Scientists, 2012d]), although still in the usual range for high-porosity sediment $(<1500)$. Several intervals with pyrite mineralizations organized as lineations and bearing low-angle planar discontinuities with associated increased CT values are tentatively interpreted as shear zones (e.g., Fig. F8 in the "Site C0018" chapter [Expedition 333 Scientists, 2012d]).

\section{Biostratigraphy}

Preliminary biostratigraphic determination for Site C0018 was based on examination of calcareous nannofossils. All core catcher samples and additional samples from sections were examined. Several nannofossil events were recognized with mostly good preservation. Although some reworked specimens were identified in the examined intervals, most specimens can be considered in situ. The result shows no significant time gap in Hole C0018A. The lowest core catcher at 313.61 mbsf indicates an age younger than $1.67 \mathrm{Ma}$. Ages derived from nannofossil events suggest a slower sedimentation rate $(\sim 6 \mathrm{~cm} / \mathrm{k} . \mathrm{y}$.) in the interval of 0-25.525 mbsf corresponding to Facies IAi and a higher apparent sedimentation rate $(\sim 23 \mathrm{~cm} / \mathrm{k} . \mathrm{y}$.) in the interval of $25.53-313.61 \mathrm{mbsf}$. This interval includes most MTDs within Subunit IA as well as Subunit IB, which is composed of sandy turbidites.

\section{Paleomagnetism}

Shipboard paleomagnetic studies for Site C0018 were performed with remanent magnetization and magnetic susceptibility measurements of discrete samples. Recovered sediments showed considerable variation in magnetic properties and demagnetization behavior. The natural remanent magnetization (NRM) intensities span more than two orders of magnitude, and variations in magnetic susceptibility are consistent with the variations in NRM intensity. Remagnetization imparted by the coring process is commonly encountered and is characterized by NRM inclinations that are strongly biased toward vertical (mostly toward $+90^{\circ}$ ) in a majority of cores. Alternating-field (AF) demagnetization to $30 \mathrm{mT}$ effectively removed this drilling-induced remagnetization, as observed by a significant decrease in intensity and a shift of inclination toward shallower or negative values for intervals with normal or reversed polarity, respectively. Magnetostratigraphy is determined based on the inclination data demagnetized at $30 \mathrm{mT}$. The most diagnostic feature in the paleomagnetic polarity is a change from normal to reversed polarity within Core 333-C0018A-14H, which corresponds to the Brunhes/Matuyama Chron boundary (0.78 Ma) (Fig. F4). According to tephra chronological data, the base of a normal chron below the thick MTD horizon is correlated to the base of Jaramillo Subchron (1.07 Ma). Cores recovered with HPCS generally show a clustered distribution in declination within each core, but the declinations in the MTD intervals are scattered. This supports irregular rotation of sediments in MTDs.

\section{Physical properties}

From the surface to $\sim 200 \mathrm{~m}$ core depth below seafloor (CSF), bulk density generally increases and porosity decreases downhole, accompanied by increasing penetration and shear strength, thermal conductivity, and resistivity (Fig. F6). Porosity and resistivity are generally correlated and, arguably, MTD intervals display an increased compaction gradient compared with the average porosity-depth trend, and slight reversals (porosity increasing with depth) are observed near the base of MTDs 2, 3, 5, and 6. For the latter case (MTD 6), this could be in part related to the lithologic change between Subunits IA and IB. Shear strength displays more scatter within MTD intervals. Within the thick MTD, all physical property values (porosity, thermal conductivity, strength, and resistivity) show greater scatter than above or below. A drop in shear strength below the thick MTD at 190 m CSF may at least in part be an artifact related to the change of coring system from HPCS to EPCS, and then ESCS. Below $200 \mathrm{~m}$ CSF, physical properties show no distinct trend.

\section{Inorganic geochemistry}

The main geochemical objective at this site was to document the variations in chemical composition of the interstitial water. Whole-round lengths ranged from 20 to $31.5 \mathrm{~cm}$, and interstitial water volumes per centimeter of core ranged from 1.95 to $2.15 \mathrm{~mL} / \mathrm{cm}$ between 0 and $130.5 \mathrm{mbsf}$ (Fig. F37 in the "Site C0018" chapter [Expedition 333 Scientists, 2012d]). Because of the consolidated nature of the formation in the deeper portion of this site and the coring techniques used, some of the deeper cores were quite disturbed. Sulfate concentration, calcium concentration, and alkalinity point to a sharp methane-sulfate reaction zone at $\sim 15$ mbsf. Below this level, we could use the sulfate concentration to identify and quantify contamination. Chlorinity in- 
creases rapidly in the upper $\sim 30 \mathrm{~m}$ of Hole C0018A and then gradually increases with depth (Fig. F38 in the "Site C0018" chapter [Expedition 333 Scientists, 2012d]). The gradual increase in chlorinity in Hole C0018A may reflect ash alteration, which consumes water. The distribution of major and minor cations documents extensive alteration of volcanogenic sediments as well (Fig. F39 in the "Site C0018" chapter [Expedition 333 Scientists, 2012d]). The thick MTD interval is associated with lower phosphate concentration. This feature is not explained.

\section{Organic geochemistry}

Methane is the predominant hydrocarbon component in most cores and ranges between 0 and 19,339 ppmv (Fig. F41 in the "Site C0018" chapter [Expedition 333 Scientists, 2012d]). Ethane is either below detection or present in low concentrations (i.e., $<2$ ppmv). No heavier hydrocarbon gases were detected. All C1/C2 ratios are $>4000$, suggesting that methane is biogenic and organic matter is immature. Calcium carbonate $\left(\mathrm{CaCO}_{3}\right)$ content averages $12.5 \mathrm{wt} \%$ and varies in a wide range (0.2 25.4 wt\%) (Fig. F42 in the "Site C0018" chapter [Expedition 333 Scientists, 2012d]). Total organic carbon (TOC), total nitrogen (TN), and total sulfur (TS) contents are low in the majority of cores, averaging $0.58 \pm 0.16,0.07 \pm 0.02$, and $0.21 \pm 0.19 \mathrm{wt} \%$, respectively. Parameters including $\mathrm{CaCO}_{3}, \mathrm{TOC}, \mathrm{TN}$, and TS contents all show larger variations in the upper $\sim 87 \mathrm{mbsf}$ and become less variable in deeper sediments. The atomic ratios of TOC to TN $\left(\mathrm{TOC} / \mathrm{TN}_{\mathrm{at}}\right)$ fall in the range of $\sim 3.5-15$, suggesting organic matter is mostly derived from marine sources but also contains terrestrial material in some horizons.

\section{Core-seismic integration}

At Site C0018, lithologic Subunits IA and IB correlate with seismic Units 1a and 1b of Kimura et al. (2011) and Strasser et al. (2011). The base of the thick MTD (MTD 6) appears very reflective in profiles from 3-D seismic data and of negative polarity. This could be related to a step increase of porosity observed at the base of MTD 6 (Fig. F6). It is unclear whether the change of physical properties observed at this level is the consequence of deformation within the MTD or of a change of lithology at the transition between lithologic Subunits IA and IB, or both. Seismic onlap surfaces above MTD 6 define the base of several suspected MTDs in seismic data. These correlate with intervals in cores with evidence for remobilization (MTDs 2, 4, and 5) (Fig. F7). The layered sequence below MTD 6 corresponds to lithologic Subunit IB, which is composed of turbidites, but these reflectors cannot be interpreted as individual events in the turbidite sequence.

\section{Downhole temperature measurements}

During HPCS operations, downhole temperature was measured with the advanced piston corer temperature tool (APCT-3) at $\sim 30 \mathrm{~m}$ intervals. Starting from $35.15 \mathrm{~m}$ drilling depth below seafloor (DSF), six data points were obtained to $190.65 \mathrm{mbsf}$, but the deepest measurements at 161.65 and $190.65 \mathrm{~m}$ DSF may be unreliable. Other data follow a nearly linear increase in temperature with depth $\left(0.0581^{\circ} \mathrm{C} / \mathrm{m}\right)$ (Fig. F8). Heat flow, which was calculated by taking into account thermal conductivity measured on cores, is 62 $\mathrm{mW} / \mathrm{m}^{2}$.

\section{Site C0011}

The main reasons for returning to Site C0011 were to perform temperature measurements for heat flow determination and expand the age-depth models into the Pliocene and Quaternary. This was necessary because the upper stratigraphic intervals of the Shikoku Basin were not adequately sampled during Expedition 322. The additional coring provided complete profiles of organic and interstitial water geochemistry, and sampled across prominent discontinuities in physical properties identified on LWD data. Site C0011 is located on the northern flank of the Kashinosaki Knoll (Fig. F9, F10).

\section{Lithology}

A total of $380 \mathrm{~m}$ of strata was drilled in Holes C0011C and C0011D (Fig. F3 in the "Site C0011" chapter [Expedition 333 Scientists, 2012b]). Two lithologic units were identified with very good recovery rates. Unit I corresponds to Shikoku Basin hemipelagic/pyroclastic facies and Unit II corresponds to a volcanic turbidite facies that was originally designated middle Shikoku Basin facies (Underwood et al., 2010). In addition, two lithologic subunits were interpreted within Unit I, Subunit IA (youngest), and Subunit IB. Cored lithologies include silty clay, clayey silt, clay, and mudstone interbedded with coarse to fine volcanic ash (Fig. F3 in the "Site C0011" chapter [Expedition 333 Scientists, 2012b]). The Subunit IA/IB boundary occurs at $251.52 \mathrm{mbsf}$ and is defined by the appearance (below) of more-indurated dark gray mud and mudstone with abundant bioturbation and by the disappearance of volcanic ash layers with unaltered glass. A more dramatic lithologic change occurs below 347.82 mbsf where we found an abrupt shift into coarsergrained tuffaceous sandstone and heterolithic gravel and sand. This change marks the Unit I/II boundary. 
Subunit IA comprises a $251.5 \mathrm{~m}$ thick succession of greenish gray silty clay with minor amounts of grayish silty clay and $<50 \mathrm{~cm}$ intercalations of volcanic ash, often bearing unaltered glass shards. Bioturbation is particularly observed in the upper part of the unit. The genera Zoophycos and Chondrites burrows are abundant. Overall, ash layers are more abundant in the upper half of the subunit to 100 mbsf (Fig. F3 in the "Site C0011" chapter [Expedition 333 Scientists, 2012b]). In addition, XRD data from the dominant silty clay lithology indicate an average content of $57 \mathrm{wt} \%$ clay minerals, $18 \mathrm{wt} \%$ quartz and feldspar, and $7 \mathrm{wt} \%$ calcite for the subunit. Variations in the relative percentage of calcite are recorded at specific intervals with a maximum in calcite abundance of $26 \mathrm{wt} \%$ at 3.16 mbsf (Fig. F13 in the "Site C0011" chapter [Expedition 333 Scientists, 2012b]). Although uncommon, siliceous fossils (diatoms, radiolarians, and sponge spicules) are present in Subunit IA.

The dominant lithology of Subunit IB is a greenish brown to dark gray weakly lithified mudstone with minor contribution of altered volcanic ash beds (Fig. F3 in the "Site C0011" chapter [Expedition 333 Scientists, 2012b]). Clay minerals and altered volcanic glass are the most abundant particles on smear slides, and an increase in the severity of glass alteration as depth increases is observed below the transition from Subunit IA to IB (Fig. F8 in the "Site C0011" chapter [Expedition 333 Scientists, 2012b]). Clay mineral content from XRD data averages 67 $\mathrm{wt} \%$ for the mudstone, ranging from 74 to $46 \mathrm{wt} \%$ (Fig. F13 in the "Site C0011" chapter [Expedition 333 Scientists, 2012b]). Quartz content ranges from 12 to $19 \mathrm{wt} \%$ and averages $17 \mathrm{wt} \%$, and feldspar ranges from 9 to $18 \mathrm{wt} \%$ and averages $12 \mathrm{wt} \%$. Calcite is present in the subunit, varying from 0 to 31 wt\% (Fig. F13 in the "Site C0011" chapter [Expedition 333 Scientists, 2012b]) and reaching a maximum near the transition from Subunit IA to IB. Siliceous microfossils are absent from smear slides (with one exception) in Subunit IB.

The upper part of Unit II is dominated by coarsergrained tuffaceous sandstone and heterolithic gravel, gravelly sandstone, and sandstone with sharp and well-defined upper and lower boundaries (Fig. F11 in the "Site C0011" chapter [Expedition 333 Scientists, 2012b]), similar to recoveries during Expedition 322 (Expedition 322 Scientists, 2010). These beds are separated by indurated mudstone very similar to that of Subunit IB. The relative clay mineral abundance drops in association with a higher percentage of sandy material. From XRD data, the content of quartz is consistent at $\sim 16 \mathrm{wt} \%$, whereas feldspar values vary from 11 to $46 \mathrm{wt} \%$. Biotite, orthopyroxene, and hornblende are common in the tuffaceous sandstones (Fig. F3 in the "Site C0011" chapter [Expedition 333 Scientists, 2012b]) (see Site C0011 smear slides in "Core descriptions"). Siliceous microfossils and fresh glass shards are found again in Unit II.

Four volcanic ash layers comprise provisional stratigraphic markers at Site C0011. Preliminary correlations are based on visual observations of the shape of the glass shards and dominant associated minerals in smear slides. The first ash layer, which correlates with the Azuki volcanic ash layer on land (0.85 Ma; Hayashida et al., 1996), occurs at 21.18 mbsf. The second ash layer, which the Pink ash correlates with (1.05 Ma; Hayashida et al., 1996), occurs at 31.30 mbsf. The correlative products of both events are preserved on land as thin discrete accumulations of ash. In addition, a bed correlative to the onland Ohta ash layer (4.0 Ma; Satoguchi et al., 2005) is present at $157.26 \mathrm{mbsf}$ and a provisional match to the onland Habutaki ash layer (2.8-2.9 Ma; Nagahashi and Satoguchi, 2007) is located at $80.56 \mathrm{mbsf}$.

XRF analyses were performed on 57 samples from Holes C0011C and C0011D to estimate the bulk chemical composition of the sediments and to characterize compositional trends with depth and/or lithologic characteristics (Fig. F11). As shown by the underlying units (Underwood et al., 2010), major element contents in the hemipelagic mud and mudstone of Unit I span a relatively small range of values, and the compositions resemble those of the upper continental crust as defined by Taylor and McLennan (1985). A few samples of volcanic ash and volcaniclastic layers were analyzed. They all have higher silica and lower aluminum content than the background sediment and slightly lower iron content but variable alkaline content. Several samples have a high-potassium rhyolite composition. Other samples, and notably the tuffaceous sandstones in Unit II, have relatively high sodium and calcium but low potassium content and correspond to more typical calco-alkaline rhyolite and dacite compositions. This variability in bulk chemistry suggests that volcanic materials originate from different sources (presumably Kyushu vs. Izu-Bonin).

The deposition mode for Subunit IA was dominated by hemipelagic settling. A small MTD is observed in the uppermost few meters of Holes C0011C and C0011D, between 0.85 and 2.77 mbsf (Core 333C0011C-1H). However, several volcanic ash layers display turbidite characteristics (basal lamination and upward fining), suggesting these were remobilized by subaqueous gravity flow. Deposition of Subunit IB was dominated by hemipelagic settling with minor contributions of coarse (sand-sized) ash and fine (silt- and clay-sized) ash that becomes more 
abundant toward the base of the subunit. During the deposition of Unit II, the paleoenvironment was dominated by transport of sand from a volcanic source. Miocene sandy turbidites have been previously identified in the Nankai Trough and Shikoku Basin. The Miocene siliciclastic turbidites at Ocean Drilling Program (ODP) Site 1177 are generally older and were derived from a relatively large land mass, most likely southern Japan. That middle-late Miocene (15-7 Ma) dispersal system spread terrigenous sediment over a broad area of the Shikoku Basin (Moore, Taira, Klaus, et al., 2001; Fergusson, 2003). Conversely, the younger tuffaceous sandstones at Site C0011, on the northeast side of the basin, have been linked to a provenance in the Izu-Bonin volcanic arc (Underwood et al., 2010).

\section{Structural geology}

Holes C0011C and C0011D provide sparse and subtle structures. Structural features encountered in Hole C0011B are subhorizontal to moderately dipping beds, high- to moderately dipping small faults, planar shear zones, and low-angle healed faults (found in lithologic Subunit IB and Unit II) (Fig. F15 in the "Site C0011" chapter [Expedition 333 Scientists, 2012b]). Sediment-fill veins (vein structures) also develop in the shallow part. In an interval from 100 mbsf to the base of logging Unit 1A (250 mbsf), beds dip consistently to the northwest of up to $30^{\circ}$, which exceeds the dip of strata above and below as well as the local slope. This tilting may tentatively be attributed to slope instability, affecting the same stratigraphic interval as observed at Site C0012. Most faults and shear zones are observed over the 30-190 mbsf interval, which may be in part due to better observations on HPCS rather than ESCS cores. Two sets of conjugate normal faults, striking north-northeastsouth-southwest and northwest-southeast can be distinguished (Fig. F18 in the "Site C0011" chapter [Expedition 333 Scientists, 2012b]). The strikes of these conjugate sets are, respectively, parallel to the $\mathrm{N} 25^{\circ}$ maximum horizontal stress direction inferred from borehole breakouts at Site C0011 (Saito et al., 2010), and orthogonal to Nankai subduction convergence $\left(300^{\circ}-310^{\circ} \mathrm{N}\right.$; Henry et al. 2001; Loveless and Meade, 2010). A north-northeast-south-southwest compression would be consistent with the local direction of compression inferred from kinematic modeling of the Zenisu-Izu fault system $\left(20^{\circ} \mathrm{N}\right.$; Mazzotti et al., 2001). Furthermore, focal mechanisms of the 2004 earthquakes off Kii Peninsula, which occurred within the oceanic plate north and northeast of Site C0011 indicate dominantly north-south compression (Ito et al., 2005). It is therefore likely that the state of stress at Site C0011 is influenced by in- traplate compressive deformation within the Philippine Sea plate.

\section{Biostratigraphy and paleomagnetism}

Shipboard paleomagnetic studies for Holes C0011C and C0011D were performed with remanent magnetization and magnetic susceptibility measurements of discrete samples. Recovered sediments showed considerable variations in magnetic properties and demagnetization behavior in Holes C0011C and C0011D. Because AF demagnetization of $30 \mathrm{mT}$ can effectively remove drilling-induced remagnetization, the remanent magnetization of $30 \mathrm{mT}$ inclinations were used for magnetostratigraphy. Shipboard paleomagnetic interpretations agree well with the preliminary identification of dated tephra events from smear slide visual description (Fig. F12). Nannofossil biostratigraphy was done postcruise, and although nannofossils were not well preserved in some intervals, datums have excellent consistency with paleomagnetic interpretations, except for the deepest one, which corresponds to the paracme end of Reticulofenestra pseudoumbilica (>7 $\mu \mathrm{m})$ (Fig. F12). This event is considered to have a low level reliability (see "Biostratigraphy" in the "Methods" chapter [Expedition 333 Scientists, 2012a]). On the other end the shipboard paleomagnetic interpretation has good continuity with Expedition 322 data, and yields an age of $7.6 \mathrm{Ma}$ for the transition between lithologic Units I and II (Fig. F13), and the age of the Subunit IA/IB boundary is constrained to $5.32 \mathrm{Ma}$ from magnetostratigraphy. Based on our data, the geologic age throughout the cores is from 0 to $\sim 7.8$ $\mathrm{Ma}$. An average sedimentation rate in the cores is calculated at $\sim 4.6 \mathrm{~cm} / \mathrm{k} . \mathrm{y}$. The sedimentation rate changes downhole from $\sim 2.7$ to $\sim 7.5 \mathrm{~cm} / \mathrm{k} . \mathrm{y}$. at $\sim 80$ mbsf (or $\sim 3.0 \mathrm{Ma}$ ). There is also an interval of slower sedimentation in lithologic Subunit IB.

\section{Physical properties}

Bulk density and resistivity values generally increase from the surface to $50 \mathrm{~m} \mathrm{CSF}$, reflecting normal consolidation of sediments (Fig. F36 in the "Site C0011" chapter [Expedition 333 Scientists, 2012b]). However, from $\sim 50$ to $80 \mathrm{~m}$ CSF density and resistivity decrease and then remain anomalously constant from 80 to $240 \mathrm{~m}$ CSF. Below $240 \mathrm{~m}$ CSF, density and resistivity increase abruptly and then continue along a normal consolidation trend. This behavior is similar to that observed at ODP Leg 190 Sites 1173 and 1177 , where the base of the zone showing retarded compaction was ascribed to dissolution of opal-CT cement and precipitation of quartz (Spinelli et al., 2007). This interpretation is further supported by the 
profile of dissolved silica at Site C0011, which shows a sharp decline beginning at $240 \mathrm{~m}$ CSF.

Sediment strength generally increases with depth, though vane shear and penetrometer measurements could not be made below $160 \mathrm{~m}$ CSF because of high sediment strength (Fig. F33 in the "Site C0011" chapter [Expedition 333 Scientists, 2012b]). Resistivity and acoustic velocity measurements conducted on discrete cubes from below $215 \mathrm{~m}$ CSF show normal trends of increasing resistivity and velocity with depth, including elevated resistivity and velocity in volcaniclastic sands at the top of Unit II (Fig. F37 in the "Site C0011" chapter [Expedition 333 Scientists, 2012b]). Anisotropies in the vertical plane show that with depth the $z$-direction becomes slower and more resistive, which is consistent with uniaxial consolidation of transversely isotropic, bedded sediments.

Two transitions were shown by LWD data at Site C0011 (Saito et al., 2010), one at 212 m LSF (downward decrease in gamma ray with a small associated decrease in resistivity) and one at $251.5 \mathrm{~m} \mathrm{LSF}$ (downward increase in resistivity and gamma ray). The transition at $251.5 \mathrm{~m} \mathrm{LSF}$ is obviously associated with the strong porosity and resistivity gradient observed between Subunits IA and IB. At this date, the upper transition is not correlated with any remarkable observations on cores except, perhaps, a $1 \mathrm{~m}$ thick silt layer at 200.4-201.4 m CSF.

During HPCS operations, downhole temperature was measured with the APCT-3 at $\sim 30 \mathrm{~m}$ intervals. We completed one measurement in Hole C0011C at 22.5 mbsf and eight measurements in Hole C0011D from 49 to 184 mbsf. Data show a nearly linear increase in temperature with depth $\left(0.0913^{\circ} \mathrm{C} / \mathrm{m}\right)(\mathrm{Fig}$. F8), corresponding to a heat flow value of $89.5 \mathrm{~mW} / \mathrm{m}^{2}$. Temperature extrapolated at basement $(\sim 1050 \mathrm{~m}$, from seismic profile), taking into account heat conductivity variations in the cored intervals, is $\sim 80^{\circ} \mathrm{C}$.

\section{Inorganic geochemistry}

Inorganic geochemical objectives at this site were to document the variations in interstitial water chemical composition in shallower depth, which were recovered during Expedition 322. Whole-round lengths ranged from 19 to $41 \mathrm{~cm}$ and interstitial water volumes per centimeter of core range from 1.7 to $2.8 \mathrm{~mL} / \mathrm{cm}$ between 0 and $378.6 \mathrm{mbsf}$ (Fig. F42 in the "Site C0011" chapter [Expedition 333 Scientists, $2012 \mathrm{~b}]$ ). Because of the more consolidated nature of the formation in the deeper portion of this site and the coring techniques used, some of the deeper cores were quite disturbed. We were able to use sulfate concentration to identify and quantify contamination in the deeper cores. Results are generally consistent between Hole C0011B (Expedition 322) and
Hole C0011C/C0011D (Expedition 333) data, except for bromide, for which there is an offset, still unexplained.

Chlorinity increases rapidly with depth in the upper $\sim 25 \mathrm{~m}$ of Holes C0011C and C0011D, stays close to seawater value from 25 to 250 mbsf in Hole C0011D, and then gradually decreases below 130 mbsf in Hole C0011D (Fig. F43 in the "Site C0011" chapter [Expedition 333 Scientists, 2012b]). The chlorinity decrease, which continues to the deeper interstitial waters of Hole C0011B taken during Expedition 322 (Underwood et al., 2010), may reflect the updip migration of interstitial water freshened by the smectite-illite reaction at greater depths below the trench and prism toe.

Another remarkable feature is a sharp drop in silica concentration (also coincidental with a lithium concentration maximum) at the level of the transition from lithologic Subunit IA to IB (Fig. F44 in the "Site C0011" chapter [Expedition 333 Scientists, 2012b]). Remarkably, this drop correlates with a decrease in porosity from $\sim 65 \%$ to $\sim 55 \%$ observed over $<10 \mathrm{~m}$ in moisture and density data as well as with a concurrent resistivity increase in LWD (Saito et al., 2010) and core data. The high $(\sim 800 \mu \mathrm{M})$ silica concentration in the fluid in Subunit IA supports the hypothesis that the retarded compaction in lithologic Subunit IA is due to a opal-CT cement, as proposed for Sites 1173 and 1177 (Spinelli et al., 2007). At the level of the tuffaceous sandstones (350-370 mbsf), a secondary silica concentration maximum is observed, which may be related to ash alteration. This interval is also characterized by higher barium concentration and slightly decreased lithium and strontium relative to the trend defined from concentrations above and below.

\section{Organic geochemistry}

Methane was the only hydrocarbon gas detected at Site C0011 and it occurs only in low concentrations (2 ppmv) in the uppermost $250 \mathrm{~m}$ of the cored sequence (Fig. F46 in the "Site C0011" chapter [Expedition 333 Scientists, 2012b]). Thereafter, methane concentration gradually increased to reach highest values ( 900 ppmv) at 380 mbsf.

TOC, TN, and TS contents are generally low in all lithologic units, averaging $0.31 \pm 0.10,0.06 \pm 0.01$ and $0.14 \pm 0.97 \mathrm{wt} \%$, respectively (Fig. F47 in the "Site C0011" chapter [Expedition 333 Scientists, $2012 \mathrm{~b}])$. At the base of Subunit IA and top of Subunit IB, several samples display higher TS values, including a pyrite-rich specimen at $\sim 12 \mathrm{wt} \%$. TOC/TN ${ }_{\mathrm{at}}$ was $5.67 \pm 1.60$, indicating a marine origin for the sedimentary organic matter. The calcium carbon content varied between 0.2 and $24.5 \mathrm{wt} \%$ and shows highest 
concentration in the upper part of Subunit IA and over the transition from Subunit IA to IB. Rock-Eval derived $T_{\max }$ values range from $399^{\circ}$ to $414^{\circ} \mathrm{C}$ and indicate a thermally immature state of the organic matter.

\section{Site $\mathrm{C0012}$}

The main objectives of returning to Site C0012 were to perform temperature measurements for heat flow determination, to expand the age-depth models into the Pliocene and Quaternary, and to core the basement to at least $100 \mathrm{~m}$ below the sediment/basement interface. Knowledge of thermal state, interstitial water geochemistry, hydrologic properties, and basement alteration are needed to characterize the state of the subduction inputs and model their evolution with downdip increases in temperature and pressure.

\section{Lithology}

In Holes C0012C and C0012D, $180 \mathrm{~m}$ of lithologic Unit I (hemipelagic/pyroclastic facies) and the upper part of lithologic Unit II (volcanic turbidite facies) were drilled during Expedition 333 (Fig. F3 in the "Site C0012" chapter [Expedition 333 Scientists, 2012c]). The remaining holes (C0012E, C0012F, and C0012G) aimed at drilling red calcareous claystone and basalt at the contact between sediments in the Shikoku Basin and the igneous oceanic crust. The cores brought new information on lithologic Unit I not acquired during Expedition 322 because of severe coring disturbance and poor recovery.

Three lithologic subunits were interpreted in Unit I: Subunit IA (youngest), Subunit IB, and Subunit IC. The subunits are distinguished based on the presence, frequency of occurrence, and thickness of volcanic ash layers. The lithologies in Holes C0012C and C0012D include dark greenish gray clay and silty clay and silt interbedded with volcanic ash and minor occurrences of thin sand. A major change in the frequency of the occurrence of ash layers is recorded at $\sim 71.5 \mathrm{mbsf}$, thereby defining the Subunit IA/IB boundary. Ash alteration was observed from 91.2 mbsf to the lower part of Subunit IB. At Site C0011, a comparable alteration front occurs at the top of Subunit IB. Within Subunit IB, ash layers are scarce to $\sim 123.3 \mathrm{mbsf}$, below which another interval of dark greenish gray clay/silty clay with abundant ash layers extends to 149.77 mbsf. This depth for the base of Unit I matches closely with the designation of $150.9 \mathrm{~m}$ CSF that was made during Expedition 322 (Underwood et al., 2010).

Below 149.77 mbsf, Unit II comprises turbidite sands and sandstones with sharp and well-defined upper and lower boundaries. Commonly, beds have normal grading, but some are intercalated with intervals of massive beds with or without clay clasts. At the base of normal graded beds, pebble and sand clasts are composed of coarse ash and lapilli tuff. The lower part of Unit II comprises several layers of carbonatecemented sandstones with calcite and barite veins. These beds are separated by mudstone very similar to that of Subunit IC. The base of Unit II was not cored during Expedition 333 but was fixed at $219.8 \mathrm{~m} \mathrm{CSF}$ in Hole C0012A (Underwood et al., 2010).

Nannofossils are the dominant group of microfossils and are found in both Units I and II. Sponge spicules, diatoms, and radiolarians occur as a rare or trace component in most of Subunit IA, being relatively more abundant at the top of the subunit. Below $\sim 85$ mbsf they were not identified. Bulk powder XRD data indicate an average content of $63 \mathrm{wt} \%$ clay minerals, with the lowest content ( 45 wt \%) characterizing the uppermost $15 \mathrm{~m}$. There is on average about $19 \mathrm{wt} \%$ quartz and $18 \mathrm{wt} \%$ feldspar; both show uniform values throughout Units I and II (Fig. F6 in the "Site C0012" chapter [Expedition 333 Scientists, 2012c]). Calcite content is highest in the upper $15 \mathrm{~m}$, where it reaches $25 \mathrm{wt} \%$ (Fig. F6 in the "Site C0012" chapter [Expedition 333 Scientists, 2012c]). Below 15 mbsf calcite content of Subunit IA is very low, dropping the average for the subunit to 4 wt $\%$ except for Subunit IB where it varies from 0 to $20 \mathrm{wt} \%$ and averages $6 \mathrm{wt} \%$. Major element concentrations of Unit I and II from XRF analyses span a relatively small range of values (Fig. F14) and resemble those of the upper continental crust as defined by Taylor and McLennan (1985).

The cored portion of Units I and II has an estimated Holocene-late Miocene age range ( 0-8.3 Ma). Three ash beds were correlated to known tephra dated on land based on visual observations of the shape of the glass shards and dominant associated minerals in smear slides. The Azuki volcanic ash bed, dated on land as 0.85 Ma (Hayashida et al., 1996) was identified at 5.7 mbsf. The Pink ash bed, dated on land as $1.05 \mathrm{Ma}$ (Hayashida et al., 1996), correlates with a characteristic ash layer at 7.7 mbsf. A third major volcaniclastic event, the Ohta ash bed, dated on land as $4.0 \mathrm{Ma}$ (Satoguchi et al., 2005), correlates with an ash bed at 44.95 mbsf (Fig. F3 in the "Site C0012" chapter [Expedition 333 Scientists, 2012c]).

The unusually shallow depths of the presumed Azuki and Pink ash beds implies very slow sedimentation rates over the last $\sim 1 \mathrm{Ma}$. This interpretation is, however, consistent with the depth of the Brunhes-Matuyama reversal and of the Jaramillo Chron from natural magnetic remanence data. This interval of condensed sedimentation lies on an angular unconformity with a hiatus of $\sim 2$ m.y. at $\sim 14$ mbsf, inter- 
preted as the top of a slump. Other, yet unresolved, hiatuses may account for the very slow apparent sedimentation rate above this unconformity.

The deposition of Subunits IA and IC was dominated by hemipelagic settling and frequent volcanic eruptions, whereas the time interval of Subunit IB experienced fewer volcanic eruptions. During deposition of the upper part of Unit II, the paleoenvironment was dominated by deposition from a sandy system with a volcanic provenance (Izu-Bonin arc). In comparison to Holes C0011C and C0011D, the Miocene sandy turbidites are finer grained on top of the bathymetric high, and the thick tuffaceous sandstone layers characteristic of the volcanic turbidite facies were not observed. On the other hand, pebbly and mixed layers evocative of MTDs were found.

Hole C0012E recovered two cores of greenish yellow mudstone intercalated with thin sandstone layers from $500 \mathrm{mbsf}$, corresponding to the base of lithologic Unit V (volcaniclastic-rich facies) defined during Expedition 322 (Underwood et al., 2010), and one core from 519 mbsf that recovered $6.8 \mathrm{~m}$ of reddish brown calcareous claystone with lighter green layers, overlying altered pillow basalts. The interface between the red calcareous claystone and the basaltic basement was also recovered in Holes C0012G and C0012F. The red calcareous claystone corresponds to Expedition 322 lithologic Unit VI (pelagic claystone) (Underwood et al., 2010) and holds veins of calcite with traces of barite as well as several layers with accumulations of manganese oxide forming millimeter- to centimeter-sized lumps.

Hole C0012G cored pillows and massive phyric basalts from 525.69 mbsf to the base of the hole at 630.5 mbsf. Two units are defined in the basalt: Unit I is composed of phyric or highly phyric pillow basalt and Unit II is composed of sheet flows with pillow basalt interlayers. As observed during Expedition 322 , the basalt in Unit I is highly altered and some voids remaining between basalt pillows are filled with analcime. Observations of thin sections showed that all olivine and glass (except in one sample) as well as a large fraction of the plagioclases have been replaced by secondary phases-dominantly saponite and zeolites-that are also present as vesicle fillings. In Unit II, the massive flows are more crystalline and generally less altered. Basalt experienced localized alteration under iron oxidizing conditions with accumulation of iron hydroxides in veins and alteration halos. Celadonite and saponite are present in the rock mass and, locally, pyrite. This suggests two stages of alteration, under iron oxidizing and iron reducing conditions.

\section{Structural geology}

Structures observed at Site C0012 mainly consist of bedding planes, faults, shear zones, and chaotic structures (Fig. F15). Bedding planes show a large range of dipping angles from $3^{\circ}$ to $70^{\circ}$ but are organized in zones of low and high bedding dips. Bedding planes with low dips are characteristically observed in Zone I (0-14 mbsf) (Fig. F15B) and Zone III (85-145 mbsf). However, high dip angle beds are found in Zone II (14-85 mbsf), where they consistently strike northeast-southwest (Fig. F15C) and dip southeast, and in Zone IV (145-180 mbsf), where the distribution of strikes and dips appears scattered. Sediment above this unconformity (between 10 and $14 \mathrm{mbsf}$ ) comprises disturbed intervals suggesting it has been reworked. Faults are mostly normal faults with high dip angles, striking northwest-southeast, and dipping northeast or southwest, suggesting northeast-southwest extension (Fig. F15D). Shear zones generally have high dip angles with large displacements. Chaotic structures are composed of disrupted beds, folds, and injections of sand or mud and observed at the bottom of Zones II and IV. Considering the location of Site C0012 on a topographic high southwest of a steep slope evocative of a slide scar, one interpretation proposed is that Zone II corresponds to a slump that was later covered by flatlying sediments, whereas Zone IV may have been affected by multiple (and older) sliding events.

Paleomagnetic and biostratigraphic data suggest that the unconformity between Zone I and Zone II correlates with an age hiatus of $\sim 2.0$ m.y. Similar observations within the upper part of Unit III during Expedition 322 suggested that a slumping event associated with the remobilization of the uppermost sedimentary layers also occurred about 9.5 m.y. ago (Underwood et al., 2010) (Fig. F13).

\section{Biostratigraphy and paleomagnetism}

Paleomagnetic shipboard studies for Site C0012 were performed with remanent magnetization and magnetic susceptibility measurements of discrete samples (Fig. F31 in the "Site C0012" chapter [Expedition 333 Scientists, 2012c]). Magnetostratigraphic correlations indicate the age of the sediments in Holes C0012C and C0012D range from present day at the seafloor to $>8 \mathrm{Ma}$ at the bottom of the hole $(\sim 180$ mbsf $)$. Following AF demagnetization to 30 $\mathrm{mT}$, inclination values were variable. Bedding correction performed on the specimens clustered the data near the expected $\sim 52^{\circ}$ but did not affect the chron and subchron boundaries. The Brunhes/Matuyama boundary was detected in Core 333-C0012C-2H, and 
provisional correlation of tephra chronology identified the Pink tephra layer in Core 333-C0012C-3H within the lower portion of the Jaramillo Subchron and the Ohta tephra layer in Core 333-C0012C-6H within the Gilbert Chron. A thickness of only $9 \mathrm{~m}$ between these two chrons indicates that the lower section of the Matuyama Chron is probably missing and this interpretation is also consistent with correlation of the magnetic susceptibility between Sites C0011 and C0012 (Fig. F31 in the "Site C0012" chapter [Expedition 333 Scientists, 2012c]). This indicates a hiatus or condensed sedimentation interval spanning roughly 2 m.y. ( $\sim 1$ to $\sim 3 \mathrm{Ma}$ ) occurring between 10 and 14 mbsf. In this interval the core presents both evidence of disturbance from drilling (flow-in below Pink ash layer) and of in situ disturbance, which precludes detailed magneto-stratigraphic interpretation. The nannofossil assemblage found in Section C0012C-2H-CC corresponds to the 0.9-1.1 Ma time interval (see Table T4 in the "Site C0012" chapter [Expedition 333 Scientists, 2012c]). It is thus proposed the hiatus occurs between Cores C0012C-2H and C0012C-3H at 14 mbsf and coincides with an angular unconformity (see "Structural geology"). Below this level, shipboard paleomagnetic interpretations and nannofossil datums from both expeditions are generally consistent, except in the 70 to 90 mbsf interval that corresponds to the base of the slump (Fig. F12). Paleomagnetic data suggest a small hiatus $(<1 \mathrm{Ma})$ may be present at $\sim 85$ mbsf across a chaotic zone, representing the probable base of the slump. Below this level, the sedimentation appears continuous. The sedimentation rate displays some variations and, notably, is faster before 7.4 Ma in lithologic Subunit IB and Unit II. The transition from Subunit IA to IB is constrained at 4.42 Ma from magnetostratigraphy, and thus appears slightly younger at Site C0012 than at Site C0011 (Fig. F13). However, a change in physical properties was observed below this level and therefore would better correlate in age with a comparable change observed at Site C0011 than the lithologic boundary. The change of the frequency of ash layer occurrence at the Subunit IB/IC boundary is constrained to 7.13 Ma from magnetostratigraphy. The age models at the depth of the transition from Unit I to Unit II are very consistent and provide an age of $7.8 \mathrm{Ma}$, slightly older than at Site C0011, but it is unclear whether this variation is significant.

\section{Physical properties}

From the surface to $\sim 10 \mathrm{~m} \mathrm{CSF}$, porosity decreases downhole, as expected for progressive burial. Below $10 \mathrm{~m} \mathrm{CSF}$, porosity slightly increases and then remains relatively constant until $\sim 70 \mathrm{~m}$ CSF, which co- incides with the lithologic Subunit IA/IB boundary (Fig. F34 in the "Site C0012" chapter [Expedition 333 Scientists, 2012c]). Within this anomalous interval, electrical resistivity also remains constant while shear strength increases, and there is an anomalous shift in the concentration of dissolved silica in the interstitial water. Between 70 and $100 \mathrm{~m} \mathrm{CSF}$, porosity sharply decreases and electrical resistivity and shear strength increase. Porosity increases and then decreases between 100 and $170 \mathrm{~m} \mathrm{CSF}$, followed by a steady compaction trend, with some scatter in sandrich units, to the base of the borehole. Sandstones are also indicated by spikes of high magnetic susceptibility and low natural gamma ray.

Site C0012 porosity values from below 240 m CSF are generally lower than those from similar depths at Site C0011 (Fig. F16). A possible explanation for the lower porosity at Site C0012 is removal of overlying material by erosion or slope failure. This interpretation would be consistent with the observed time gap of $\sim 2$ m.y. found between 10 and $14 \mathrm{~m} \mathrm{CSF}$ and the structural evidence of an angular unconformity. Calcareous claystones from below $500 \mathrm{~m}$ CSF range in porosity from 0.28 to 0.46 and show $P$-wave velocities $\sim 2000 \mathrm{~m} / \mathrm{s}$ (Fig. F17). Within the basalt, measured porosity is extremely variable and ranges from 0.09 to 0.37 . Measured $P$-wave velocities vary between 3000 and $5000 \mathrm{~m} / \mathrm{s}$.

Electrical resistivity is greater in the z-direction within the claystones but lower within the basement. Higher resistivity in the z-direction in the sediments is consistent with a transversely isotropic medium in which the bedding planes are approximately horizontal (Fig. F17). Within the basement, electrical conductivity may be enhanced by subvertical veins or fractures filled with more conductive material, resulting in a lower resistivity in the $z$-direction.

Thermal gradient values are evaluated from the APCT-3 measurements made at 10 depths in Holes C0012C and C0012D together, and the mean thermal gradient value determined is $0.135 \mathrm{~K} / \mathrm{m}$ (Fig. F8). The estimated heat flow value at this site is 141 $\mathrm{mW} / \mathrm{m}^{2}$, amounting to $\sim 50 \%$ higher than the 89.5 $\mathrm{mW} / \mathrm{m}^{2}$ determined for the adjacent Hole C0011C that was drilled during this expedition. Based on the determined heat flow value of $141 \mathrm{~mW} / \mathrm{m}^{2}$, as well as the thermal conductivity values from core measurements (see also, Expedition 322 Scientists, 2010), temperature at the top of basement (at $526 \mathrm{mbsf}$ ) is estimated to be $\sim 65^{\circ} \mathrm{C}$, which is significantly lower than the estimated value of $80^{\circ} \mathrm{C}$ at $\sim 1050 \mathrm{~m}$ CSF at Site C0011. We suspect that hydrothermal fluid convection in the basement is transferring heat between the two sites, thus resulting in a higher heat flow at 
Site C0012, which is located on the topographic high. However, the effect of sedimentation on heat flow, and also of sediment removal by gravity sliding at Site C0012, should also be considered in models.

\section{Inorganic geochemistry}

The main objective of the inorganic geochemistry program at this site was to document the geochemical properties of subduction inputs at a site located above a basement high, near the crest of the Kashinosaki Knoll. A total of 28 interstitial water samples were squeezed from selected whole-round sections for chemical and isotopic analyses. To obtain enough interstitial water for shipboard and shorebased analyses, 19-31 cm long sections were squeezed in Holes C0012C and C0012D. In the red claystone located directly above the basement in Hole C0012E, sections 59.5-61 cm in length were squeezed. Interstitial water volumes per length of interstitial water section decrease with depth, from 2.75 to $0.71 \mathrm{~mL} / \mathrm{cm}$ of core in the upper $\sim 180 \mathrm{mbsf}$ of Holes C0012C and C0012D (Fig. F45 in the "Site C0012" chapter [Expedition 333 Scientists, 2012c]). In the deeper material above the basement, volumes were lower, ranging from 0.22 to $0.08 \mathrm{~mL} / \mathrm{cm}$.

The sulfate profile for Site C0012 documents a much deeper sulfate reduction zone than observed at the other sites drilled during this expedition. At Site C0011, the zone occurs at $\sim 80 \mathrm{mbsf}$, and at Site C0018 it occurs at 15 mbsf. During Expedition 322 it was observed that minimum sulfate concentration, which occurs at $\sim 300 \mathrm{~m} \mathrm{CSF}$ at Site C0012, coincides with a marked increase in methane concentration (Saito et al., 2010). The Expedition 322 scientists interpreted the sulfate profile at Site $\mathrm{C0012}$ as being driven locally by anaerobic methane oxidation. The deeper anomaly was attributed to slower sedimentation rates (because of the bathymetric high Site C0012 sits on), to a lower average organic matter content at Site C0012, or to differences in fluid migration. Additionally, in both Holes C0012E and C0012A sulfate increases in concentration in the interval below $\sim 450 \mathrm{~m} \mathrm{CSF}$, which may indicate diffusional exchange with fluid in basaltic basement that sustain a higher sulfate concentration.

In general, analytical results are consistent between Expeditions 333 and 322 (Figs. F46, F47 in the "Site C0012" chapter [Expedition 333 Scientists, 2012c]) and interpretations proposed after Expedition 322 are not put in question by the newly acquired data. However, shipboard Br concentrations during Expedition 333 tend to be systematically lower, whereas $\mathrm{Li}$ and $\mathrm{Sr}$ concentrations tend to be higher. Overall, the combined data set reflects in situ alteration of volcanic ash in the sediment and basalt alteration in the upper igneous crust as well as exchange by diffusion. More specifically, the decrease in $\mathrm{Mg}$ and $\mathrm{K}$, increase in Li and Sr, and variations in silica (Fig. F47 in the "Site C0012" chapter [Expedition 333 Scientists, 2012c]) in the upper $200 \mathrm{~m}$ are probably controlled by volcanic ash alteration and equilibration of the interstitial fluid with clay minerals.

Silica concentration drops below the Subunit IA/IB boundary at $\sim 70 \mathrm{~m}$, where a decrease in porosity and an increase in resistivity are also observed. Alteration of volcanic glass shards also becomes more pronounced. This again suggests a relationship between interstitial water composition, the presence or dissolution of opal cement, and ash diagenesis. However, the silica concentration remains relatively high and variable in the 200-500 $\mu \mathrm{M}$ range from 90 to $200 \mathrm{~m}$ and then, according to Expedition 322 data, decreases again. These local variations do not fit existing models for opal dissolution and quartz precipitation (Spinelli et al., 2007), which suggests that additional sources of silica are present (e.g., volcanic ash alteration) and that dissolved silica concentration in this interval is not limited by quartz precipitation.

The trend of increasing chlorinity (Fig. F46 in the "Site C0012" chapter [Expedition 333 Scientists, 2012c]), Ca, and Sr (Fig. F47 in the "Site C0012" chapter [Expedition 333 Scientists, 2012c]) concentrations and decreasing $\mathrm{Na}$ in the lower part of the borehole is interpreted as a consequence of diffusion between the lowermost sediment and basement fluids.

\section{Organic geochemistry}

At Site C0012, methane and ethane were either below detection or present at only low concentrations. No heavier hydrocarbon gases (i.e., C3 and C4) were found. The only two samples that contained both methane and ethane were found at depths of $\sim 501$ and $\sim 520 \mathrm{mbsf}$ and had C1/C2 ratios $<100$, indicating a possible thermogenic origin of these hydrocarbon gases (Fig. F18). Calcium carbonate $\left(\mathrm{CaCO}_{3}\right)$ concentration ranged between 0.2 and $45.1 \mathrm{wt} \%$ and averaged $6.1 \mathrm{wt} \%$ (Fig. F19). Sediment below 500 mbsf contained higher amounts of $\mathrm{CaCO}_{3}$ compared to the upper $180 \mathrm{mbsf}$ of the cored sequence. TOC, $\mathrm{TN}$, and TS concentrations were low, ranging between 0.03 and $0.46 \mathrm{wt} \%, 0.03$ and $0.07 \mathrm{wt} \%$, and 0 and $0.49 \mathrm{wt} \%$, respectively. The TOC/TN $\mathrm{at}$ fell in the range of 1.3-9.3, suggesting a marine origin of the organic matter. The variations of these four elemental parameters shared a similar pattern, including scattered values but displaying a generally increasing trend with depth in the upper 52 mbsf relatively uni- 
form values between 52 and 180 mbsf, as well as low values between $\sim 500$ and 525 mbsf.

\section{Preliminary scientific assessment}

Expedition 333 achieved its primary objectives regarding the sedimentary sequence. Basement coring was limited to the upper $100 \mathrm{~m}$ as a consequence of adverse weather conditions and a technical failure (destruction of [polycrystalline diamond compact drill bit [PDC]). Yet, additional cores from across the sediment/basalt interface and from basalt obtained at deeper levels than during Expedition 322 will yield important shore-based results. Temperature measurements with the APCT- 3 at all three sites and thermal conductivity measurements on cores yielded precise determinations of heat flow, which are slightly lower than shallow heat flow probe data acquired on the Kumano transect (Kinoshita et al., 2008). Cores filling the gaps between the seafloor and the top of RCB coring during Expedition 322 were recovered, and some overlap was achieved to provide a continuous data set. The sediment/basement interface was recovered again, with ESCS in Hole C0012E and RCB in Holes C0012F and C0012G, and interstitial fluid samples were extracted again from the sediment immediately above the interface. The $8.20 \mathrm{~m}$ core taken across the interface with ESCS was of very good quality. Postcruise work on these new samples will complement the analyses performed on Expedition 322 cores, notably with fluid isotopic chemistry and hydrological and mechanical tests.

At the NanTroSLIDE site, coring with HPCS, EPCS, and finally ESCS provided nearly continuous recovery across a thick MTD (our primary target) near its edge. The depth, thickness, age, composition, and structural character of this MTD were determined, as well as that of several thinner intervals of sediment disturbed by slope instability processes. The target depth (350 mbsf) was not drilled, but sufficient recovery was achieved below the thick MTD to 314 mbsf to characterize the underlying sediments as a turbidite sequence holding little evidence for postdepositional remobilization. The primary goals of drilling at Site C0018 were thus reached. Tephrochronology, paleomagnetism, and micropaleontology results are consistent, and good quality dating will be obtained over most of the cored interval in spite of the reworking of sediment inherent to a MTD sequence. The age of the thick MTD can already be bracketed between $0.85 \mathrm{Ma}$ and $1.05 \mathrm{Ma}$ from two ash layers of known age. Most HPCS cores taken within the MTD are of good quality and were sampled for shore-based geotechnical measure- ments. A thick ash layer lying immediately below the MTD was given special attention.

Data acquired during Expedition 333 address important questions regarding the state of material input to the subduction zone, which were left partially unanswered after Expedition 322. Some results on heat flow, stratigraphy, physical properties, and diagenesis are already well established by the end of the expedition. These, combined with knowledge acquired at other Nankai area drill sites (IODP and ODP) provide a basis for preliminary interpretations and orientation for postcruise studies. Other questions, notably regarding basement and sediment-basement fluid interaction, can only be achieved by postcruise work. Another important aspect of the NanTroSLIDE site is ground-truthing of MTD occurrences, based on seismic reflection images. Coring brought simple answers to several of the questions asked and some unexpected findings. The sedimentological and structural observations lead to refined hypotheses on MTD processes and their interaction with tectonic activity and sedimentation on Nankai margin.

\section{Can a change of physical properties between 200 and 250 mbsf at Site $\mathrm{C0011}$ be related to lithologic variation or diagenesis? Does the same transition occur at Site C0012?}

A major change of physical properties is found at $\sim 250 \mathrm{mbsf}$ at Site C0011 and has tentatively been identified between 70 and 90 mbsf at Site C0012. This transition appears as a lithologically determined feature enhanced by diagenesis. The content of discrete ash layers in the sediment decreases below this boundary and an increase of the state of alteration of volcanic glass shards is observed in the remaining ash layers. Siliceous fossils are also present above, and there is a sharp decrease in dissolved silica concentration below the boundary. From an analogy with results obtained after Leg 190, it can be proposed that the process responsible for an anomalously high porosity of the sediment above this boundary is cementation by opal-CT and opal dissolution with precipitation of quartz below the boundary (Spinelli et al., 2007). However, the temperature of the reaction would be unusually low at Site C0011 (currently $25^{\circ} \mathrm{C}$, as opposed to $55^{\circ} \mathrm{C}$ at Site 1173) and, assuming constant heat flow, cannot be explained with the reaction kinetics used by Spinelli et al. (2007); and fresh glass is found again in volcaniclastic sands at a deeper level, associated with high silica concentration in the interstitial water. Furthermore, in the case of Sites C0011 and C0012, the primary silica source is dispersed volcanic glass rather than biogenic opal-A (White et al., 2010). It thus remains questionable that the transition observed is 
controlled by the kinetics of the opal-A/opal-CT and opal-CT/quartz reactions. An alternate possibility is that opal-CT do not form in sufficient amounts to prevent compaction if the initial concentration of amorphous silica in the sediment is too low. Answering these questions will require postcruise work.

Chronostratigraphy based on paleomagnetism and biostratigraphy suggests the age of the transition from opal-cemented hemipelagic mud with numerous ash layers to compacted hemipelagic mudstone with sparce ash layers at Site C0011 (5.25 Ma) is slightly younger at Site 1177 (4.5 Ma), the reference site for the Ashizuri transect. It is even younger at Site 1173 (3.0 Ma), the reference site for the Muroto transect, where higher heat flow and temperature can account for a more advanced silica diagenesis and result in an upward migration of the transition in the sedimentary column (Spinelli et al., 2007). On the Kumano transect, this transition could represent an initial state of diagenesis.

\section{Is fluid circulation in basement and permeable sedimentary layers influencing heat flow and diagenesis at Sites $\mathrm{C0011}$ and C0012?}

Heat flow measured during Expedition 333 is 90 $\mathrm{mW} / \mathrm{m}^{2}$ at Site $\mathrm{C} 0011$ and $140 \mathrm{~mW} / \mathrm{m}^{2}$ at Site C0012, respectively $\sim 20 \%$ lower and 30\% higher than the heat flow expected from conductive cooling of a $20 \mathrm{Ma}$ lithosphere (Kinoshita et al., 2008). The temperatures extrapolated to basement are, respectively, $79^{\circ}$ and $65^{\circ} \mathrm{C}$ at Sites C0011 and C0012. Large variations of heat flow correlated with basement topography are often reported in zones where off-ridge hydrothermal convection is occurring and may be accounted for by supercritical Rayleigh convection (e.g., Fisher et al., 2003). Such a mechanism could account for the heat flow contrast between Site C0011 located on the flank of the Kashinosaki Knoll where sediment thickness is $\sim 1 \mathrm{~km}$ and Site C0012, located near its summit where sediment thickness is $520 \mathrm{~m}$. Whether larger scale fluid circulation in the basement (Spinelli and Wang, 2008), rather than mantle and magmatic processes, should be invoked to explain regionally elevated heat flow in the eastern part of the Shikoku Basin remains an open question.

Data acquired during Expedition 333 provide few new arguments in favor of fluid flow along permeable sedimentary horizons. At Site C0011, a higher Ba concentration is observed at the level of the presumably permeable volcanic turbidite facies (Unit II), as well as slightly higher ( $\mathrm{Ca}$ and $\mathrm{K}$ ) and lower ( $\mathrm{Sr}$ and $\mathrm{Li}$ ) concentrations of several other elements. These are possibly influenced by lateral flow. However, rigorous assessment of lateral flow will require postcruise modeling with consideration of local equilibrium and diagenetic reactions. This is now possible due to successful heat flow measurements.

\section{How does contrasting interstitial water chemistry at Sites $\mathrm{C} 0011$ and $\mathrm{C} 0012$ relate with in situ diagenesis, fluid flow, and heat flow?}

Temperature and heat flow determinations indicate that the temperature conditions in the uppermost basement at Site C0011 are within the temperature window for the onset of the smectite-illite reaction $\left(\sim 55^{\circ}-90^{\circ} \mathrm{C}\right)$. Unfortunately, coring during Expedition 322 was aborted almost $200 \mathrm{~m}$ above the top of basement at Site C0011. Although it is unlikely that the reaction has progressed to a significant extent in any of the cored sections, illitization should be expected in the lower part of Site C0011 and it should continue into the trench where the Shikoku Basin sediments are buried to greater depths. Overall, the temperature conditions at correlative stratigraphic levels do not vary by more than $\sim 15^{\circ} \mathrm{C}$ between the two drill sites. Consequently, differences in fluid composition observed between the two sites (e.g., increasing versus decreasing chlorinity toward basement) cannot result solely from in situ reactions in the cored intervals but reflect different processes occurring in the lower part of the sedimentary column and, perhaps, basement.

Is magmatic activity heterogeneous in composition and age on a backarc basin basement high? Is alteration of the upper oceanic basement heterogeneous, and how does it influence geochemical and fluid budgets?

These questions can only be answered postcruise, but preliminary analyses do not indicate heterogeneity in composition in the $100 \mathrm{~m}$ cored. Early oxidizing alteration localized around fractures and pillow rims may be distinguished from pervasive replacement under reducing conditions of glass and mineral phases (olivine and, often, plagioclases) by saponite and zeolites, which may preclude precise radiometric dating. Core recovery was poor in the upper part of the basement but improved downward as advance was reduced. Although drilling operations during Expedition 333 demonstrate the possibility for the $\mathrm{D} / \mathrm{V}$ Chikyu to maintain a steady rate of penetration while coring in basement, suggestions for improving efficiency and core quality may be driven by our experience as well as that of Expedition 322.

\section{Other questions at input sites}

We already pointed out an important outcome of Expedition 333, which is the description of a transition in physical properties and lithology that has strong similarities (sharp porosity decrease with depth, vari- 
ation in ash occurrence and alteration state, and variation in silica concentration in the interstitial water) with transitions observed on the Muroto and Ashizuri transects at the facies boundary between the upper and lower Shikoku Basin. The depth of this basin-wide transition is at least in part determined by silica diagenesis (Spinelli et al., 2007) and, as may be expected for a diagenetic front, is diachronous, ranging from 5.25 Ma at Site C0011 to 2.5-3 Ma on the Muroto transect (Moore et al., 2001). On the other hand, Expedition 322 identified important local variations in facies in the middle and lower part of the sedimentary column (>7.5 Ma), which led to the definition of the Shikoku Basin volcanic turbidite facies (Underwood et al., 2010). In this context, it is remarkable that the active décollement of the accretionary wedge is located in the 5-7 Ma interval on the Muroto and Ashizuri transects (Moore et al., 2001) and, arguably, also in the same 5-7 Ma interval on the Kumano transect, based on chronostratigraphic data from the base of the hanging wall at frontal thrust Sites C0006 and C0007 (Kinoshita, Tobin, Ashi, Kimura, Lallemant, Screaton, Curewitz, Masago, Moe, and the Expedition 314/315/316 Scientists, 2009) and on the correlation between Site C0011 stratigraphy and seismic profiles (Moore et al., 2009; Underwood et al., 2010). Compared with deposits above and below, this interval may be characterized by fewer (or absent) ash layers and an absence of turbidites. Understanding how the main décollement apparently localizes in a specific sedimentary facies in spite of lateral stratigraphic heterogeneity (or, more specifically, understanding the relationships between the décollement, the diagenetic front above, and the absence or presence of one or several turbidite sequences below) remains an important problem.

Site C0012 appears strongly influenced by mass wasting processes. First, a sedimentation hiatus is found between $\sim 1.2$ and $\sim 3$ Ma. Second, the sediments below the hiatus down to $90 \mathrm{mbsf}$ are affected by rotation of bedding, with dips up to $60^{\circ}$. Disturbed sediments evocative of MTDs were also found in the lowermost part of the interval cored during Expedition 333, as already noticed at these depths during Expedition 322. A deeper occurrence of an unconformity above slumped sediment at $\sim 9.5 \mathrm{Ma}$ was documented during Expedition 322 (Underwood et al., 2010), and an even longer hiatus is evident along an unconformity within Unit $\mathrm{V}$ near the base of the sedimentary section.

Repetition of mass wasting events is very understandable considering the location of Site C0012 immediately above the edge of a major slide scar that is obvious in the bathymetry and seismic data. How this process may affect heat flow data should be taken into consideration in modeling efforts. Mass wasting (possibly combined with fluid movement) may also help explain the high variability of seafloor heat flow probe measurements (Kinoshita et al., 2008). Furthermore, considering Site C0012 as a reference for sedimentation deposited on a structural high in the Shikoku Basin may bring a better understanding of stratigraphy within the accretionary wedge. For instance, Sites C0006 and C0007 at the toe of the accretionary wedge display a hiatus over the same age range (1.2-3 Ma) as Site C0012, below the transition between the Shikoku Basin hemipelagic/pyroclastic facies and the distal trench deposits. We wonder whether the hiatus in the hanging wall of the frontal thrust is related to the original depositional environment, which may also have been a basement high, or is the consequence of later deformation during offscraping.

\section{What is the frequency of submarine landslides near the megasplay fault?}

The spacing between intervals where evidence for sediment remobilization was observed in the cores at Site C0018 suggests submarine slope destabilization does not occur systematically during subduction earthquakes. The recurrence of great subduction earthquakes in the Nankai Trough is of the order of 100-200 y, whereas the recurrence of MTDs at Site C0018 is on the $100,000-200,000$ y timescale. The rhythm of turbidite deposition on the slope in lithologic Subunit IB below the main MTD is probably on the $1000 \mathrm{y}$ timescale and thus may not be controlled by the earthquake cycle either.

\section{What is the source material of the MTDs? What is the importance of accretionary wedge remobilization versus surficial processes?}

The MTDs sampled are remobilized slope sediments in agreement with current seismic interpretation. This, however, does not preclude that the underlying accretionary wedge could have been affected by earlier mass wasting events, or that part of the sediment deposited on this slope originate from erosion of the outer arc high (Strasser et al., 2011). Careful documentation of compositional differences between matrix and clasts should help to answer this question.

\section{What controls type, size, and magnitude of turbidites and MTDs, and how do they change through time?}

MTDs display a wide range of thicknesses from about $50 \mathrm{~cm}$ to $20-60 \mathrm{~m}$ for the thickest deposits, which can be imaged by seismic data. Processes of sediment mobilization may differ depending on the scale of 
the event and comparison of the thick MTD with smaller scale ones observed in the slope sediment sequence above will bring important insight.

Turbidite type deposits were found at the top of two MTDs and likely result from the deposition of sediments suspended during the event. However, most turbidites found at this site appear unrelated to the MTDs.

\section{How do large MTDs relate with the timing of splay fault} activity as inferred from NanTroSEIZE Stage 1 drilling?

All MTDs cored are younger than $1 \mathrm{Ma}$, and therefore postdate the main phase of activity of this splay fault branch as defined by Strasser et al. (2009) and Kimura et al. (2011).

\section{What are the dynamics of large submarine landslides, and can we infer their tsunamigenic potential?}

One important aim of postcruise research will be to understand the relationship between variations in the geotechnical properties of the sediment and occurrence and size of instabilities. We hypothesize that the occurrences of large tsunamigenic submarine landslides, in subduction zones as elsewhere, require specific conditions, such as the presence of discrete layers sensitive to liquefaction at some depth (several tens of meters) below the seafloor. These layers may, for example, correspond to loose granular material or to strain softening clays.

\section{Other questions regarding the NanTroSLIDE site}

The finding of such a pronounced transition from turbidite-dominated sedimentation to hemipelagite and ash across the thick MTD at $\sim 1$ Ma was not expected. However, this may reflect a change of depositional environment observed in this part of the accretionary wedge slope: there are few sand/silt turbidites over the last 1-1.3 Ma at Sites C0004 and C0008 and over the last $1.6 \mathrm{Ma}$ at Site C0001 (Kinoshita, Tobin, Ashi, Kimura, Lallemant, Screaton, Curewitz, Masago, Moe, and the Expedition $314 / 315 / 316$ Scientists, 2009). One possible explanation is that the uplift of the outer arc high at 1.3-1 Ma (Gulick et al., 2010) confined most of the transverse turbidity currents to the Kumano forearc basin and thus shut off sand input to the vicinity of Site C0018. Alternatively, the local evolution observed could correspond to a local change of slope and depositional environment from a perched basin trapping sand transported by turbidity currents to a more steeply inclined slope environment.

Another important outcome of observation on cores is the heterogeneous nature of deformation within MTD deposits. Chaotic, pebbly, or mixed sediment intervals coexist with intervals of coherent bedding dips. Localized deformation structures such as shear zones and fault were also identified. As observations on core are done at a smaller scale than the resolution of seismic profiles, the transparent appearance of the MTD on these profiles can be understood even though they often retain coherent intervals. However, the inner style of deformation of the MTDs cored at Site C0018 is more akin to slumps, dominated by plastic deformation, than to mud flows behaving as fluid.

\section{References}

Alves, T.M., and Lourenço, S.D.N, 2010. Geomorphologic features related to gravitational collapse: submarine landsliding to lateral spreading on a late Miocene-Quaternary slope (SE Crete, eastern Mediterranean). Geomorphology, 123(1-2):13-33. doi:10.1016/ j.geomorph.2010.04.030

Ashi, J., Kuramoto, S., Morita, S., Tsunogai, U., Goto, S., Kojima, S., Okamoto, T., Ishimura, T., Ijiri, A., Toki, T., Kudo, S., Asai, S., and Utsumi, M., 2002. Structure and cold seep of the Nankai accretionary prism off Kumano-outline of the off Kumano survey during YK01-04 Leg 2 cruise. JAMSTEC J. Deep-Sea Res., 20:1-8. (in Japanese, with abstract in English)

Bangs, N.L.B., Gulick, S.P.S., and Shipley, T.H., 2006. Seamount subduction erosion in the Nankai Trough and its potential impact on the seismogenic zone. Geology, 34(8):701-704. doi:10.1130/G22451.1

Byrne, D.E., Davis, D.M., and Sykes, L.R., 1988. Loci and maximum size of thrust earthquakes and the mechanics of the shallow region of subduction zones. Tectonics, 7(4):833-857. doi:10.1029/TC007i004p00833

Conin, M., Henry, P., Bourlange, S., Raimbourg, H., and Reuschlé, T., 2011. Interpretation of porosity and LWD resistivity from the Nankai accretionary wedge in light of clay physicochemical properties: evidence for erosion and local overpressuring. Geochem., Geophys., Geosyst., 12:Q0AD07. doi:10.1029/2010GC003381

DeMets, C., Gordon, R.G., and Argus, D.F., 2010. Geologically current plate motions. Geophys. J. Int., 181(1):1-80. doi:10.1111/j.1365-246X.2009.04491.x

Dessa, J.-X., Operto, S., Kodaira, S., Nakanishi, A., Pascal, G., Uhira, K., and Kaneda, Y., 2004. Deep seismic imaging of the eastern Nankai Trough, Japan, from multifold ocean bottom seismometer data by combined travel time tomography and prestack depth migration. J. Geophys. Res., [Solid Earth], 109(B2):B02111. doi:10.1029/ 2003JB002689

Expedition 322 Scientists, 2010. Site C0011. In Saito, S., Underwood, M.B., Kubo, Y., and the Expedition 322 Scientists, Proc. IODP, 322: Tokyo (Integrated Ocean Drilling Program Management International, Inc.). doi:10.2204/iodp.proc.322.103.2010

Expedition 333 Scientists, 2012a. Methods. In Henry, P., Kanamatsu, T., Moe, K., and the Expedition 333 Scientists, Proc. IODP, 333: Tokyo (Integrated Ocean Drilling 
Program Management International, Inc.). doi:10.2204/iodp.proc.333.102.2012

Expedition 333 Scientists, 2012b. Site C0011. In Henry, P., Kanamatsu, T., Moe, K., and the Expedition 333 Scientists, Proc. IODP, 333: Tokyo (Integrated Ocean Drilling Program Management International, Inc.). doi:10.2204/iodp.proc.333.104.2012

Expedition 333 Scientists, 2012c. Site C0012. In Henry, P., Kanamatsu, T., Moe, K., and the Expedition 333 Scientists, Proc. IODP, 333: Tokyo (Integrated Ocean Drilling Program Management International, Inc.). doi:10.2204/iodp.proc.333.105.2012

Expedition 333 Scientists, 2012d. Site C0018. In Henry, P., Kanamatsu, T., Moe, K., and the Expedition 333 Scientists, Proc. IODP, 333: Tokyo (Integrated Ocean Drilling Program Management International, Inc.). doi:10.2204/iodp.proc.333.103.2012

Fergusson, C.L., 2003. Provenance of Miocene-Pleistocene turbidite sands and sandstones, Nankai Trough, Ocean Drilling Program Leg 190. In Mikada, H., Moore, G.F., Taira, A., Becker, K., Moore, J.C., and Klaus, A. (Eds.), Proc. ODP, Sci. Results, 190/196: College Station, TX (Ocean Drilling Program), 1-28. doi:10.2973/ odp.proc.sr.190196.205.2003

Fisher, A.T., 1998. Permeability within basaltic oceanic crust. Rev. Geophys., 36(2):143-182. doi:10.1029/ 97RG02916

Fisher, A.T., Stein, C.A., Harris, R.N., Wang, K., Silver, E.A., Pfender, M., Hutnak, M., Cherkaoui, A., Bodzin, R., and Villinger, H., 2003. Abrupt thermal transition reveals hydrothermal boundary and role of seamounts within the Cocos plate. Geophys. Res. Lett., 30(11):1550-1553. doi:10.1029/2002GL016766

Frey-Martínez, J., Cartwright, J., and James, D., 2006. Frontally confined versus frontally emergent submarine landslides: a 3D seismic characterisation. Mar. Pet. Geol., 23(5):585-604. doi:10.1016/j.marpetgeo.2006.04.002

Gulick, S.P.S., Bangs, N.L.B., Moore, G.F., Ashi, J., Martin, K.M., Sawyer, D.S., Tobin, H.J., Kuramoto, S., and Taira, A., 2010. Rapid forearc basin uplift and megasplay fault development from 3D seismic images of Nankai margin off Kii Peninsula, Japan. Earth Planet. Sci. Lett., 300(12):55-62. doi:10.1016/j.epsl.2010.09.034

Hayashida, A., Kamata, H., and Danhara, T., 1996. Correlation of widespread tephra deposits based on paleomagnetic directions: link between a volcanic field and sedimentary sequences in Japan. Quat. Int., 34-36:8998. doi:10.1016/1040-6182(95)00072-0

Heki, K., 2007. Secular, transient and seasonal crustal movements in Japan from a dense GPS array: implication for plate dynamics in convergent boundaries. In Dixon, T., and Moore, C. (Eds.), The Seismogenic Zone of Subduction Thrust Faults: New York (Columbia Univ. Press), 512-539.

Henry, P., Mazzotti, S., and Le Pichon, X., 2001. Transient and permanent deformation of central Japan estimated by GPS: 1. Interseismic loading and subduction kinematics. Earth Planet. Sci. Lett., 184(2):443-453. doi:10.1016/S0012-821X(00)00335-6
Henry, P., Mazzotti, S., Maury, R., Robert, C., and Lallemant, S.J., 1997. Uplifted oceanic crust outcrops on Zenisu Ridge. JAMSTEC J. Deep-Sea Res., 13:509-520. http://docsrv.godac.jp/MSV2_DATA/23/13_39.pdf

Ike, T., Moore, G.F., Kuramoto, S., Park, J-O., Kaneda, Y., and Taira, A., 2008a. Tectonics and sedimentation around Kashinosaki Knoll: a subducting basement high in the eastern Nankai Trough. Isl. Arc, 17(3):358-375. doi:10.1111/j.1440-1738.2008.00625.x

Ike, T., Moore, G.F., Kuramoto, S., Park, J.-O., Kaneda, Y., and Taira, A., 2008b. Variations in sediment thickness and type along the northern Philippine Sea plate at the Nankai Trough. Isl. Arc, 17(3):342-357. doi:10.1111/ j.1440-1738.2008.00624.x

Ito, Y., and Obara, K., 2006. Dynamic deformation of the accretionary prism excites very low frequency earthquakes. Geophys. Res. Lett., 33(2):LO2311. doi:10.1029/ 2005GL025270

Ito, Y., Matsumoto, T., Kimura, H., Matsubayashi, H., Obara, K., and Sekiguchu, S., 2005. Spatial distribution of centroid moment tensor solutions for the 2004 off Kii Peninsula earthquakes. Earth Planets Space, 57(4):351-356. http://www.terrapub.co.jp/journals/ EPS/pdf/2005/5704/57040351.pdf

Kimura, G., and Ludden, J., 1995. Peeling oceanic crust in subduction zones. Geology, 23(3):217-220. doi:10.1130/ 0091-7613(1995)023<0217:POCISZ>2.3.CO;2

Kimura, G., Moore, G.F., Strasser, M., Screaton, E., Curewitz, D., Streiff, C., and Tobin, H., 2011. Spatial and temporal evolution of the megasplay fault in the Nankai Trough. Geochem., Geophys., Geosyst., 12:Q0A008. doi:10.1029/2010GC003335

Kinoshita, M., Kanamatsu, T., Kawamura, K., Sibata, T., Hamamoto, H., and Fujino, K., 2008. Heat flow distribution on the floor of Nankai Trough off Kumano and implications for the geothermal regime of subducting sediments. JAMSTEC J. Deep-Sea Res., 8:13-28. http:// docsrv.godac.jp/MSV2_DATA/23/

JAM_RandD08_02.pdf

Kinoshita, M., Tobin, H., Ashi, J., Kimura, G., Lallemant, S., Screaton, E.J., Curewitz, D., Masago, H., Moe, K.T., and the Expedition 314/315/316 Scientists, 2009. Proc. IODP, 314/315/316: Washington, DC (Integrated Ocean Drilling Program Management International, Inc.). doi:10.2204/iodp.proc.314315316.2009

Kodaira, S., Nakanishi, A., Park, J.-O., Ito, A., Tsuru, T., and Kaneda, Y., 2003. Cyclic ridge subduction at an interplate locked zone off central Japan. Geophys. Res. Lett., 30(6):1339-1342. doi:10.1029/2002GL016595

Kodaira, S., Takahashi, N., Nakanishi, A., Miura, S., and Kaneda, Y., 2000a. Subducted seamount imaged in the rupture zone of the 1946 Nankaido earthquake. Science, 289(5476):104-106. doi:10.1126/science.289.5476.104

Kodaira, S., Takahashi, N., Park, J.-O., Mochizuki, K., Shinohara, M., and Kimura, S., 2000b. Western Nankai Trough seismogenic zone: results from a wide-angle ocean bottom seismic survey. J. Geophys. Res., [Solid Earth], 105(B3):5887-5905. doi:10.1029/1999JB900394 
Kopf, A., Araki, E., Toczko, S., and the Expedition 332 Scientists, 2011. NanTroSEIZE Stage 2: riserless observatory. IODP Prel. Rept., 332. doi:10.2204/

iodp.pr.332.2011

Lallemand, S.E., Malavieille, J., and Calassou, S., 1992. Effects of oceanic ridge subduction on accretionary wedges: experimental modeling and marine observations. Tectonics, 11(6):1301-1313. doi:10.1029/ 92TC00637

Lallemant, S., Chamot-Rooke, N., Le Pichon, X., and Rangin, C., 1989. Zenisu Ridge: a deep intraoceanic thrust related to subduction, off southwest Japan. Tectonophysics, 160(1-4):151-153, 157-174. doi:10.1016/ 0040-1951(89)90389-2

Lay, T., Kanamori, H., Ammon, C.J., Nettles, M., Ward, S.N., Aster, R.C., Beck, S.L., Bilek, S.L., Brudzinski, M.R., Butler, R., DeShon, H.R., Ekström, G., Satake, K., and Sipkin, S., 2005. The great Sumatra-Andaman earthquake of 26 December 2004. Science, 308(5725):11271133. doi:10.1126/science. 1112250

Le Pichon, X., Iiyama, T., Chamley, H., Charvet, J., Faure, M., Fujimoto, H., Furuta, T., Ida, Y., Kagami, H., Lallemant, S., Leggett, J., Murata, A., Okada, H., Rangin, C., Renard, V., Taira, A., and Tokuyama, H., 1987a. Nankai Trough and the fossil Shikoku Ridge: results of Box 6 Kaiko survey. Earth Planet. Sci. Lett., 83(1-4):186-198. doi:10.1016/0012-821X(87)90065-3

Le Pichon, X., Iiyama, T., Chamley, H., Charvet, J., Faure, M., Fujimoto, H., Furuta, T., Ida, Y., Kagami, H., Lallemant, S., Leggett, J., Murata, A., Okada, H., Rangin, C., Renard, V., Taira, A., and Tokuyama, H., 1987b. The eastern and western ends of Nankai Trough: results of Box 5 and Box 7 Kaiko survey. Earth Planet. Sci. Lett., 83(1-4):199-213. doi:10.1016/0012-821X(87)90066-5

Le Pichon, X., Wmant, S., Tokuyama, H., Thoué, F., Huchon, P., and Henry, P., 1996. Structure and evolution of the backstop in the eastern Nankai Trough area (Japan): implications for the soon-to-come Tokai earthquake. Island Arc, 5(4):440-454. doi:10.1111/j.14401738.1996.tb00164.x

Lee, C., Nott, J.A., and Keller, F.B., 2004. Seismic expression of the Cenozoic mass transport complexes, deepwater Tarfaya-Agadir Basin, offshore Morocco. Proc.-Annu. Offshore Technol. Conf., 36:16741-MS. doi:10.4043/ 16741-MS

Loveless, J.P., and Meade, B.J., 2010. Geodetic imaging of plate motions, slip rates, and partitioning of deformation in Japan. J. Geophys. Res., [Solid Earth], 115(B2):B02410. doi:10.1029/2008JB006248

Martin, K.M., Gulick, S.P.S., Bangs, N.L.B., Moore, G.F., Ashi, J., Park, J.-O., Kuramoto, S., and Taira, A., 2010. Possible strain partitioning structure between the Kumano fore-arc basin and the slope of the Nankai Trough accretionary prism. Geochem., Geophys., Geosyst., 11:Q0AD02. doi:10.1029/2009GC002668

Mazzotti, S., Henry, P., and Le Pichon, X., 2001. Transient and permanent deformation of central Japan estimated by GPS: 2. Strain partitioning and arc-arc collision. Earth Planet. Sci. Lett., 184(2):455-469. doi:10.1016/ S0012-821X(00)00336-8
Mazzotti, S., Lallemant, S.J., Henry, P., Le Pichon, X., Tokuyama, H., and Takahashi, N., 2002. Intraplate shortening and underthrusting of a large basement ridge in the eastern Nankai subduction zone. Mar. Geol., 187(1-2):63-88. doi:10.1016/S0025-3227(02)00245-1

Mazzotti, S., Le Pichon, X., Henry, P., and Miyazaki, S.-I., 2000. Full interseismic locking of the Nankai and JapanWest Kuril subduction zones: an analysis of uniform elastic strain accumulation in Japan constrained by permanent GPS. J. Geophys. Res., [Solid Earth], 105(B6):13159-13178. doi:10.1029/2000JB900060

Moore, G.F., Bangs, N.L., Taira, A., Kuramoto, S., Pangborn, E., and Tobin, H.J., 2007. Three-dimensional splay fault geometry and implications for tsunami generation. Science, 318(5853):1128-1131. doi:10.1126/science. 1147195

Moore, G.F., Park, J.-O., Bangs, N.L., Gulick, S.P., Tobin, H.J., Nakamura, Y., Sato, S., Tsuji, T., Yoro, T., Tanaka, H., Uraki, S., Kido, Y., Sanada, Y., Kuramoto, S., and Taira, A., 2009. Structural and seismic stratigraphic framework of the NanTroSEIZE Stage 1 transect. In Kinoshita, M., Tobin, H., Ashi, J., Kimura, G., Lallemant, S., Screaton, E.J., Curewitz, D., Masago, H., Moe, K.T., and the Expedition 314/315/316 Scientists, Proc. IODP, 314/315/316: Washington, DC (Integrated Ocean Drilling Program Management International, Inc.). doi:10.2204/iodp.proc.314315316.102.2009

Moore, G.F., Taira, A., Klaus, A., Becker, L., Boeckel, B., Cragg, B.A., Dean, A., Fergusson, C.L., Henry, P., Hirano, S., Hisamitsu, T., Hunze, S., Kastner, M., Maltman, A.J., Morgan, J.K., Murakami, Y., Saffer, D.M., SánchezGómez, M., Screaton, E.J., Smith, D.C., Spivack, A.J., Steurer, J., Tobin, H.J., Ujiie, K., Underwood, M.B., and Wilson, M., 2001. New insights into deformation and fluid flow processes in the Nankai Trough accretionary prism: results of Ocean Drilling Program Leg 190. Geochem., Geophys., Geosyst., 2(10):1058. doi:10.1029/ 2001GC000166

Moore, G.F., Taira, A., Klaus, A., et al., 2001. Proc. ODP, Init. Repts., 190: College Station, TX (Ocean Drilling Program). doi:10.2973/odp.proc.ir.190.2001

Moore, J.C., and Saffer, D., 2001. Updip limit of the seismogenic zone beneath the accretionary prism of southwest Japan: an effect of diagenetic to low-grade metamorphic processes and increasing effective stress. Geology, 29(2):183-186. doi:10.1130/00917613(2001)029<0183:ULOTSZ>2.0.CO;2

Nagahashi, Y., and Satoguchi, Y., 2007. Stratigraphy of the Pliocene to Lower Pleistocene marine formations in Japan on the basis of tephra beds correlation. Quat. Res. (Daiyonki Kenkyu), 46(3):205-213. doi:10.4116/ jaqua.46.205

Nakanishi, A., Takahashi, N., Park, J.-O., Miura, S., Kodaira, S., Kaneda, Y., Hirata, N., Iwasaki, T., and Nakamura, M., 2002. Crustal structure across the coseismic rupture zone of the 1944 Tonankai earthquake, the central Nankai Trough seismogenic zone. J. Geophys. Res., 107(B1):2007. doi:10.1029/2001JB000424

Obana, K., Kodaira, S., and Kaneda, Y., 2004. Microseismicity around rupture area of the 1944 Tonankai earth- 
quake from ocean bottom seismograph observations. Earth Planet. Sci. Lett., 222(2):561-572. doi:10.1016/ j.epsl.2004.02.032

Obara, K., and Ito, Y., 2005. Very low frequency earthquakes excited by the 2004 off the Kii Peninsula earthquakes: a dynamic deformation process in the large accretionary prism. Earth, Planets Space, 57(4):321-326.

Okino, K., Shimakawa, Y., and Nagaoka, S., 1994. Evolution of the Shikoku Basin. J. Geomagn. Geoelectr., 46(6):463-479.

Park, J.-O., Moore, G.F., Tsuru, T., Kodaira, S., and Kaneda, Y., 2004. A subducted oceanic ridge influencing the Nankai megathrust earthquake rupture. Earth Planet. Sci. Lett., 217(1-2):77-84. doi:10.1016/S0012821X(03)00553-3

Park, J.-O., Tsuru, T., Kaneda, Y., Kono, Y., Kodaira, S., Takahashi, N., and Kinoshita, H., 1999. A subducting seamount beneath the Nankai accretionary prism off Shikoku, southwestern Japan. Geophys. Res. Lett., 26(7):931-934. doi:10.1029/1999GL900134

Park, J.-O., Tsuru, T., Kodaira, S., Cummins, P.R., and Kaneda, Y., 2002. Splay fault branching along the Nankai subduction zone. Science, 297(5584):1157-1160. doi:10.1126/science.1074111

Park, J.-O., Tsuru, T., No, T., Takizawa, K., Sato, S., and Kaneda, Y., 2008. High-resolution 3D seismic reflection survey and prestack depth imaging in the Nankai Trough off southeast Kii Peninsula. Butsuri Tansa, 61:231-241. (in Japanese, with abstract in English)

Ruff, L., and Kanamori, H., 1983. Seismic coupling and uncoupling at subduction zones. Tectonophysics, 99(24):99-117. doi:10.1016/0040-1951(83)90097-5

Saffer, D., McNeill, L., Byrne, T., Araki, E., Toczko, S., Eguchi, N., Takahashi, K., and the Expedition 319 Scientists, 2010. Proc. IODP, 319: Tokyo (Integrated Ocean Drilling Program Management International, Inc.). doi:10.2204/iodp.proc.319.2010

Saffer, D.M., and Marone, C., 2003. Comparison of smectite- and illite-rich gouge frictional properties: application to the updip limit of the seismogenic zone along subduction megathrusts. Earth Planet. Sci. Lett., 215(12):219-235. doi:10.1016/S0012-821X(03)00424-2

Saffer, D.M., and McKiernan, A.W., 2009. Evaluation of in situ smectite dehydration as a pore water freshening mechanism in the Nankai Trough, offshore southwest Japan. Geochem., Geophys., Geosyst., 10(2):Q02010. doi:10.1029/2008GC002226

Saffer, D.M., Underwood, M.B., and McKiernan, A.W., 2008. Evaluation of factors controlling smectite transformation and fluid production in subduction zones: application to the Nankai Trough. Isl. Arc, 17(2):208230. doi:10.1111/j.1440-1738.2008.00614.x

Saito, S., Underwood, M.B., and Kubo, Y., 2009. NanTroSEIZE Stage 2: subduction inputs. IODP Sci. Prosp., 322. doi:10.2204/iodp.sp.322.2009

Saito, S., Underwood, M.B., and Kubo, Y., and the Expedition 322 Scientists, 2010. Proc. IODP, 322: Tokyo (Integrated Ocean Drilling Program Management International, Inc.). doi:10.2204/iodp.proc.322.2010
Satoguchi, Y., Higuchi, Y., and Kurokawa, K., 2005. Correlation of the Ohta tephra bed in the Tokai group with a tephra in the Miura group, central Japan. Chishitsugaku Zasshi, 111(2):74-86.

Schnellmann, M., Anselmetti, F.S., Giardini, D., and McKenzie, J.A., 2005. Mass movement-induced fold-andthrust belt structures in unconsolidated sediments in Lake Lucerne (Switzerland). Sedimentology, 52(2):271289. doi:10.1111/j.1365-3091.2004.00694.x

Screaton, E.J., Kimura, G., Curewitz, D., and the Expedition 316 Scientists, 2009. Expedition 316 summary. In Kinoshita, M., Tobin, H., Ashi, J., Kimura, G., Lallemant, S., Screaton, E.J., Curewitz, D., Masago, H., Moe, K.T., and the Expedition 314/315/316 Scientists, Proc. IODP, 314/315/316: Washington, DC (Integrated Ocean Drilling Program Management International, Inc.). doi:10.2204/iodp.proc.314315316.131.2009

Scudder, R.P., Murray, R.W., and Plank, T., 2009. Dispersed ash in deeply buried sediment from the northwest Pacific Ocean: an example from the Izu-Bonin arc (ODP Site 1149). Earth Planet. Sci. Lett., 284(3-4):639-648. doi:10.1016/j.epsl.2009.05.037

Seno, T., Stein, S., and Gripp, A.E., 1993. A model for the motion of the Philippine Sea plate consistent with NUVEL-1 and geological data. J. Geophys. Res., [Solid Earth], 98(B10):17941-17948. doi:10.1029/93JB00782

Solheim, A., Berg, K., Forsberg, C.F., and Bryn, P., 2005. The Storegga Slide complex: repetitive large scale sliding with similar cause and development. In Solheim, A., Bryn, P., Berg, K., and Mienert, J. (Eds.), Ormen Langean Integrated Study for the Safe Development of a DeepWater Gas Field within the Storegga Slide Complex, NE Atlantic Continental Margin. Mar. Pet. Geol., 22(1-2):97107. doi:10.1016/j.marpetgeo.2004.10.013

Spinelli, G.A., Mozley, P.S., Tobin, H.J., Underwood, M.B., Hoffman, N.W., and Bellew, G.M., 2007. Diagenesis, sediment strength, and pore collapse in sediment approaching the Nankai Trough subduction zone. Geol. Soc. Am. Bull., 119(3-4):377-390. doi:10.1130/ B25920.1

Spinelli, G.A., and Underwood, M.B., 2005. Modeling thermal history of subducting crust in Nankai Trough: constraints from in situ sediment temperature and diagenetic reaction progress. Geophys. Res. Lett., 32(9):L09301. doi:10.1029/2005GL022793

Spinelli, G.A., and Wang, K., 2008. Effects of fluid circulation in subduction crust on Nankai margin seismogenic zone temperatures. Geology, 36(11):887-890. doi:10.1130/G25145A.1

Strasser, M., Moore, G.F., Kimura, G., Kitamura, Y., Kopf, A.J., Lallemant, S., Park, J.-O., Screaton, E.J., Su, X., Underwood, M.B., and Zhao, X., 2009. Origin and evolution of a splay fault in the Nankai accretionary wedge. Nat. Geosci., 2(9):648-652. doi:10.1038/ngeo609

Strasser, M., Moore, G., Kimura, G., Kopf, A., Underwood, M., Guo, J., and Screaton, E., 2011. Slumping and masstransport deposition in the Nankai forearc: evidence from IODP drilling and 3-D reflection seismic data. Geochem., Geophys., Geosyst. 12:Q0AD13. doi:10.1029/ 2010GC003431 
Taylor, S.R., and McLennan, S.M., 1985. The Continental Crust: Its Composition and Evolution: Oxford (Blackwell Scientific).

Tobin, H.J., and Kinoshita, M., 2006a. Investigations of seismogenesis at the Nankai Trough, Japan. IODP Sci. Prosp., NanTroSEIZE Stage 1. doi:10.2204/ iodp.sp.nantroseize1.2006

Tobin, H.J., and Kinoshita, M., 2006b. NanTroSEIZE: the IODP Nankai Trough Seismogenic Zone Experiment. Sci. Drill., 2:23-27. doi:10.2204/iodp.sd.2.06.2006

Underwood, M.B., 2007. Sediment inputs to subduction zones: why lithostratigraphy and clay mineralogy matter. In Dixon, T., and Moore, J.C. (Eds.), The Seismogenic Zone of Subduction Thrust Faults: New York (Columbia Univ. Press), 42-85.

Underwood, M.B., Saito, S., Kubo, Y., and the Expedition 322 Scientists, 2010. Expedition 322 summary. In Saito, S., Underwood, M.B., and Kubo, Y., and the Expedition 322 Scientists, Proc. IODP, 322: Tokyo (Integrated Ocean
Drilling Program Management International, Inc.). doi:10.2204/iodp.proc.322.101.2010

Wang, K., and Hu, Y., 2006. Accretionary prisms in subduction earthquake cycles: the theory of dynamic Coulomb wedge. J. Geophys. Res., [Solid Earth], 111(B6):B06410. doi:10.1029/2005JB004094

Yamano, M., Kinoshita, M., Goto, S., and Matsubayashi, O., 2003. Extremely high heat flow anomaly in the middle part of the Nankai Trough. Phys. Chem. Earth, 28(911):487-497. doi:10.1016/S1474-7065(03)00068-8

White, R.J., Spinelli, G.A., Mozley, P.S., and Dunbar, N.W., 2010. Importance of volcanic glass alteration to sediment stabilization: offshore Japan. Sedimentology, 58(5):1138-1154. doi:10.1111/j.13653091.2010.01198.x

Publication: 18 May 2012

MS 333-101 
Figure F1. Bathymetric map, with 2-D MCS profile locations, NanTroSEIZE Stage 1 and 2 drill sites (white circles), and Expedition 333 drill sites (red circles). White barbed line = position of deformation front of accretionary prism, yellow arrow = estimated far-field vectors between Philippine Sea plate and Japan (Seno et al. 1993; Heki, 2007).

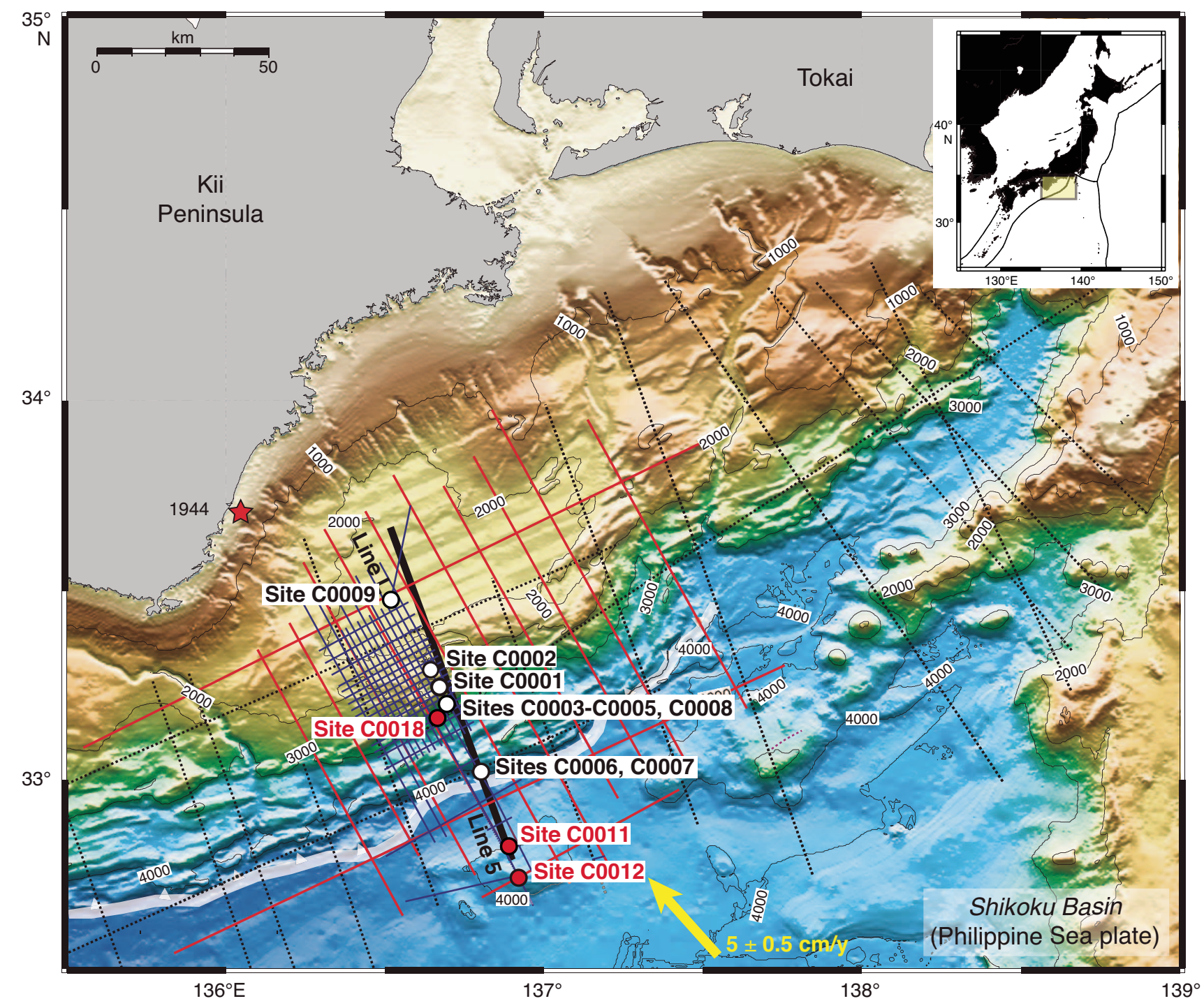


Figure F2. Spliced composite profile of a representative depth section from NanTroSEIZE 3-D data volume (Moore et al., 2009) and Line 95 from IFREE mini-3-D seismic survey (Park et al., 2008). Projected positions of Stage 1 and 2 drilling sites, including Sites C0018, C0011, and C0012, are shown.

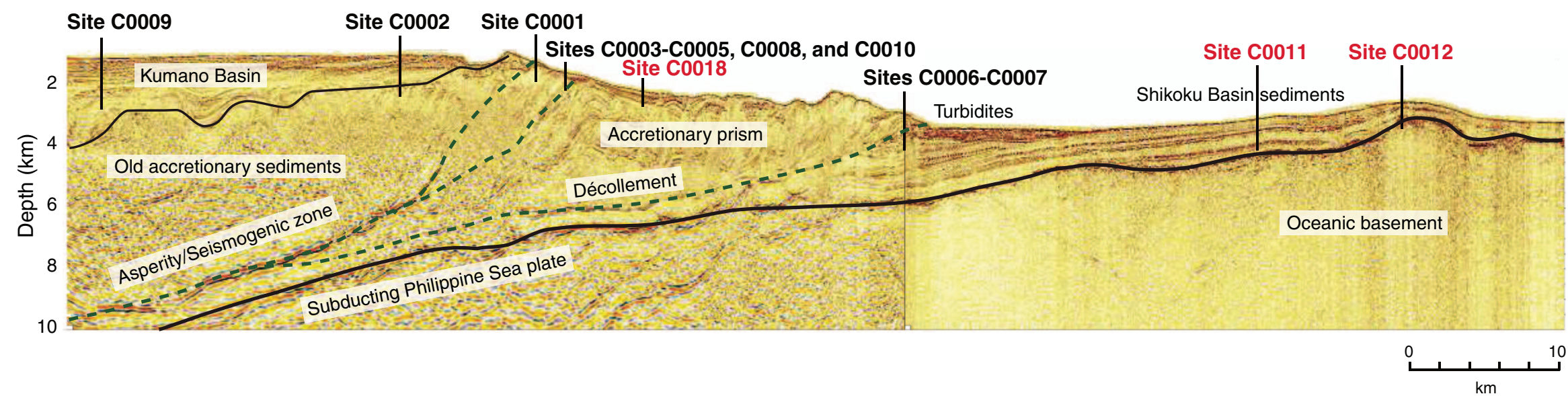


Figure F3. Detailed bathymetry and structure around Site C0018 at the footwall of the splay fault (Strasser et al., 2011). Block diagram and MCS cross-lines (XLs). IL = in-line, VE = vertical exaggeration.
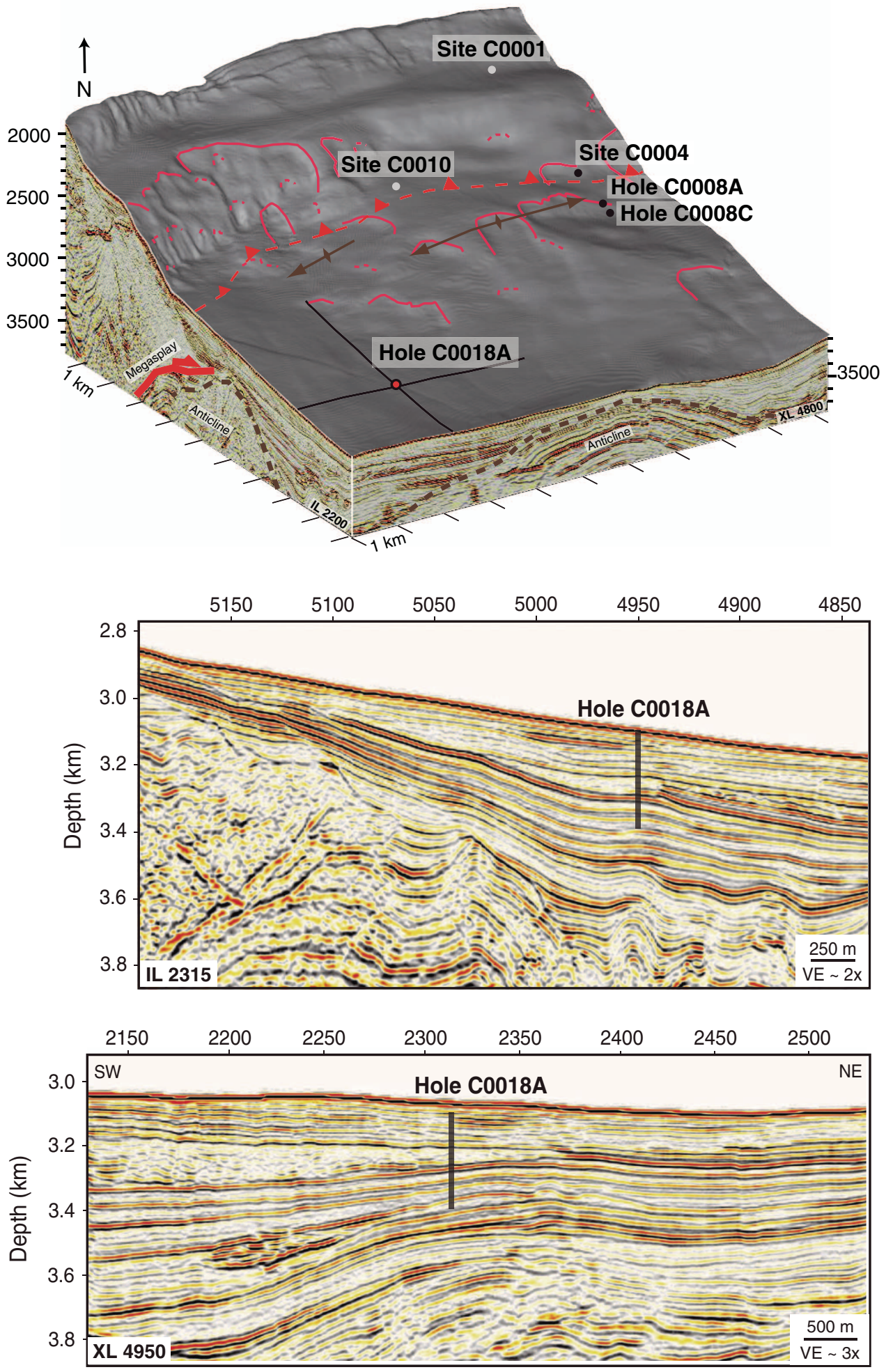
Figure F4. Schematic sedimentary log, Hole C0018A. MTD = mass transport deposit. FO = first occurrence, LO $=$ last occurrence, $\mathrm{LCO}=$ last consistent occurrence, $\mathrm{FCO}=$ first consistent occurrence.

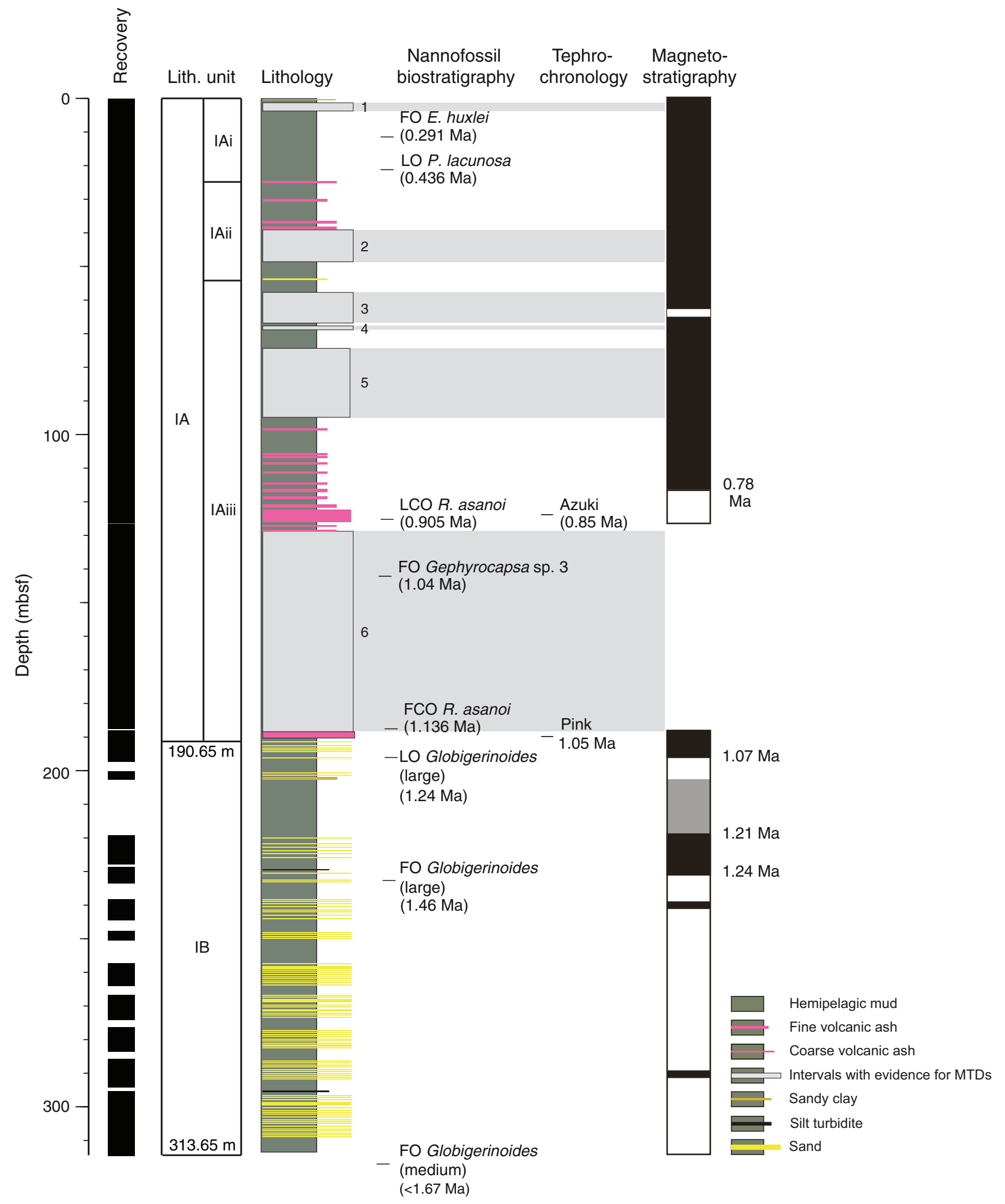


Figure F5. Lower-hemisphere equal-area projections, Hole C0018A. A. Poles to bedding above MTD. B. Poles to fault above MTD. C. Poles to folded bedding plane (black circles) and fold axis (green triangle) of slump fold (Fig. F16 in the "Site C0018" chapter [Expedition 333 Scientists, 2012d]). D. Poles to bedding and fissility below MTD.
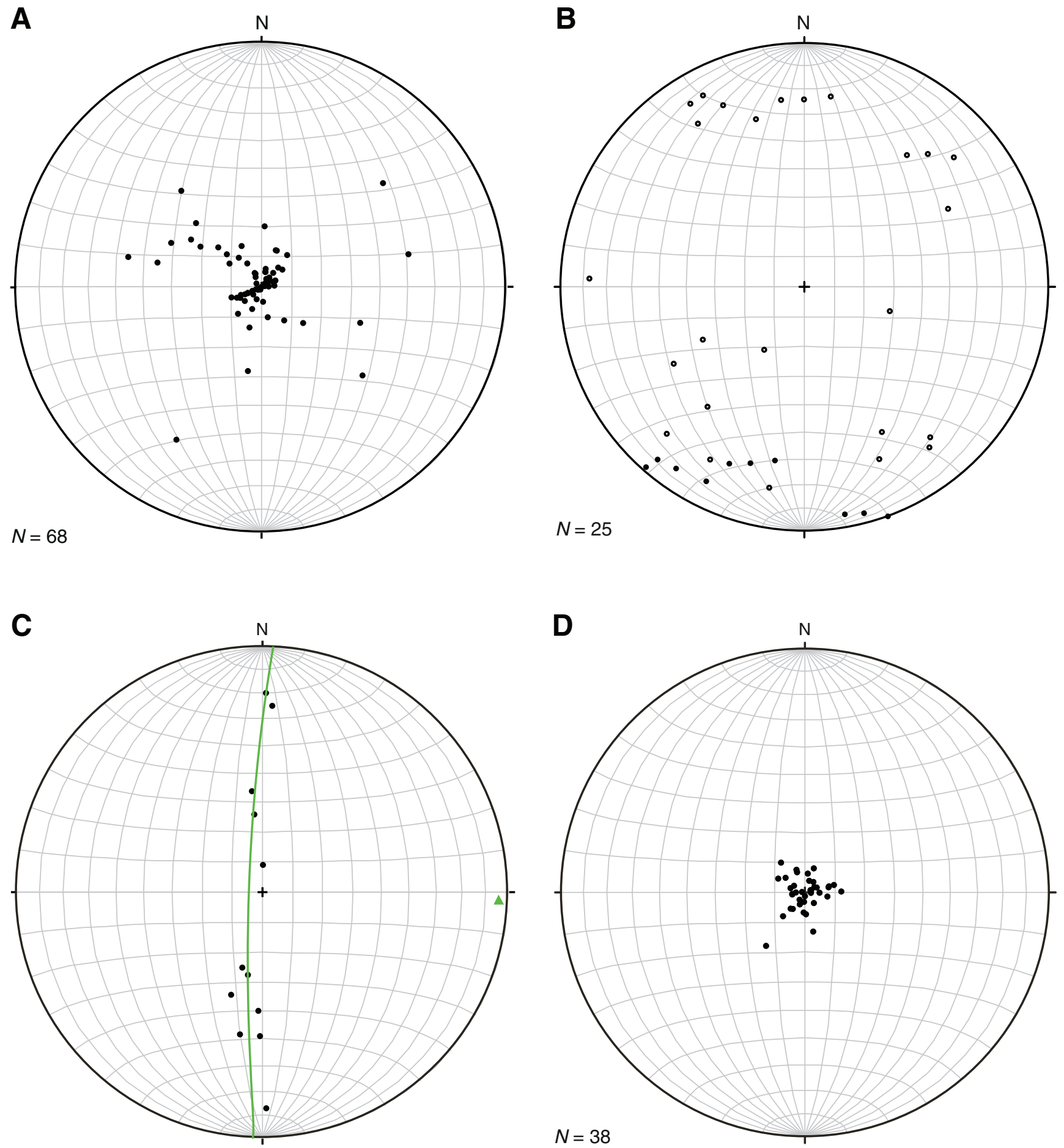
Figure F6. Summary of physical properties, porosity, shear strength, and resistivity, Site C0018. MTD = mass transport deposit. For porosity, blue $=\mathrm{mud} /$ silt samples, red $=$ sand/ash samples.

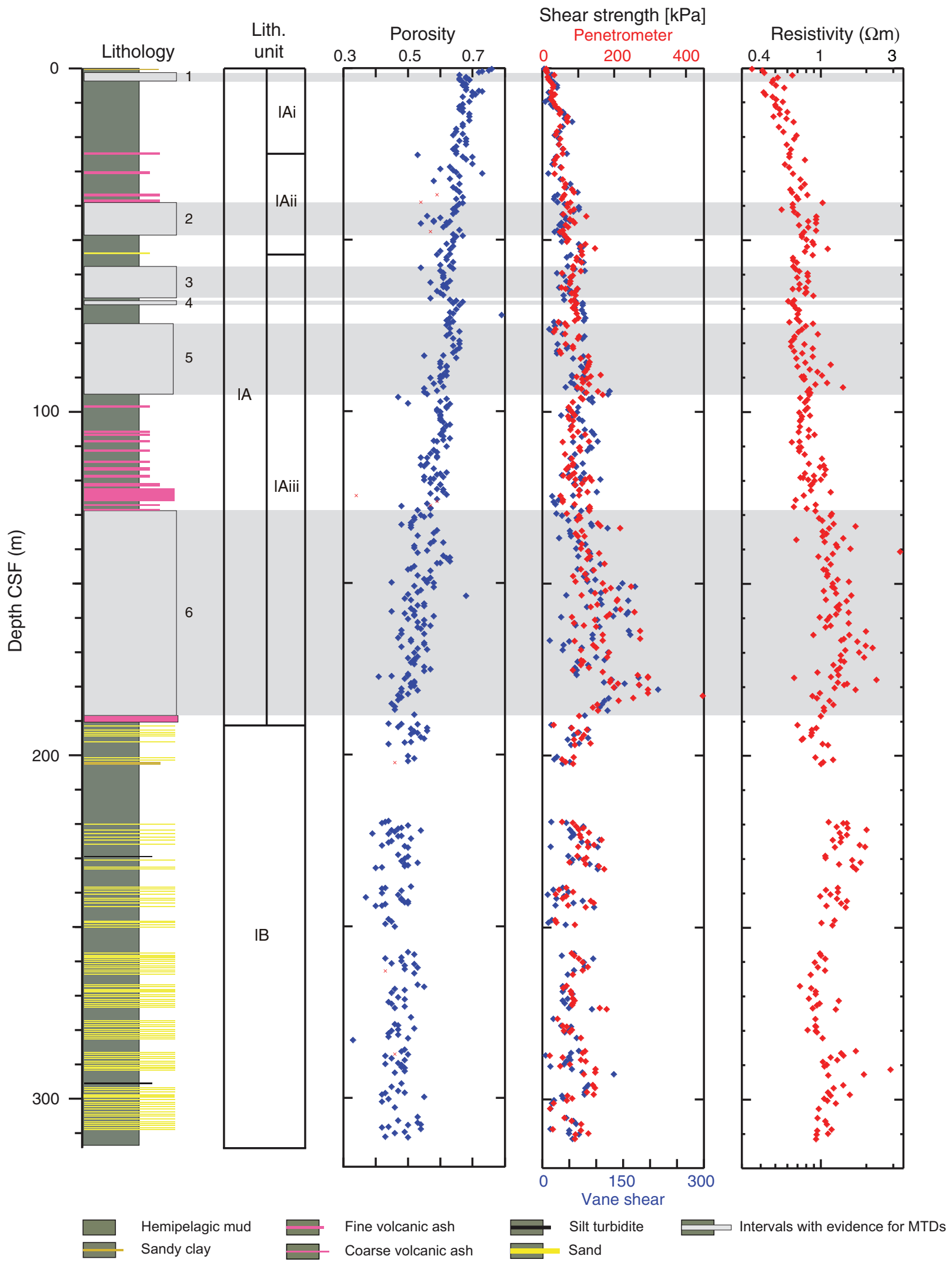


Figure F7. Lithology of Site C0018 on seismic profile. $\mathrm{IL}=$ in-line, $\mathrm{VE}=$ vertical exaggeration. $\mathrm{B}, \mathrm{G}, \mathrm{N}$, and $\mathrm{O}=$ key seismic horizons. MTD = mass transport deposit. Figure modified after Strasser et al. (2011).
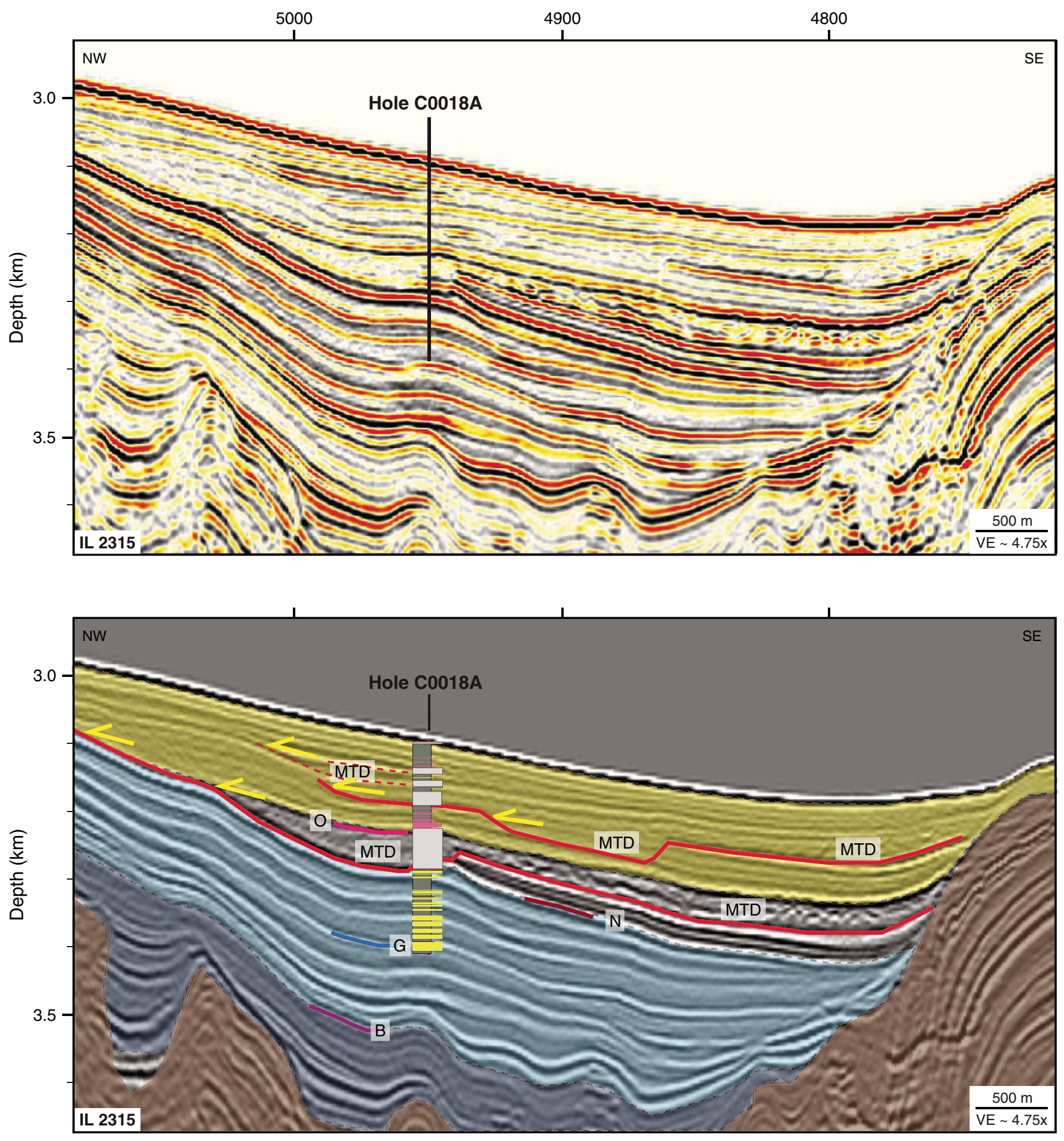
Figure F8. Summary of formation temperature measurements performed with APCT-3, Sites C0011, C0012, and C0018. Thermal gradient estimations from linear fit are indicated.

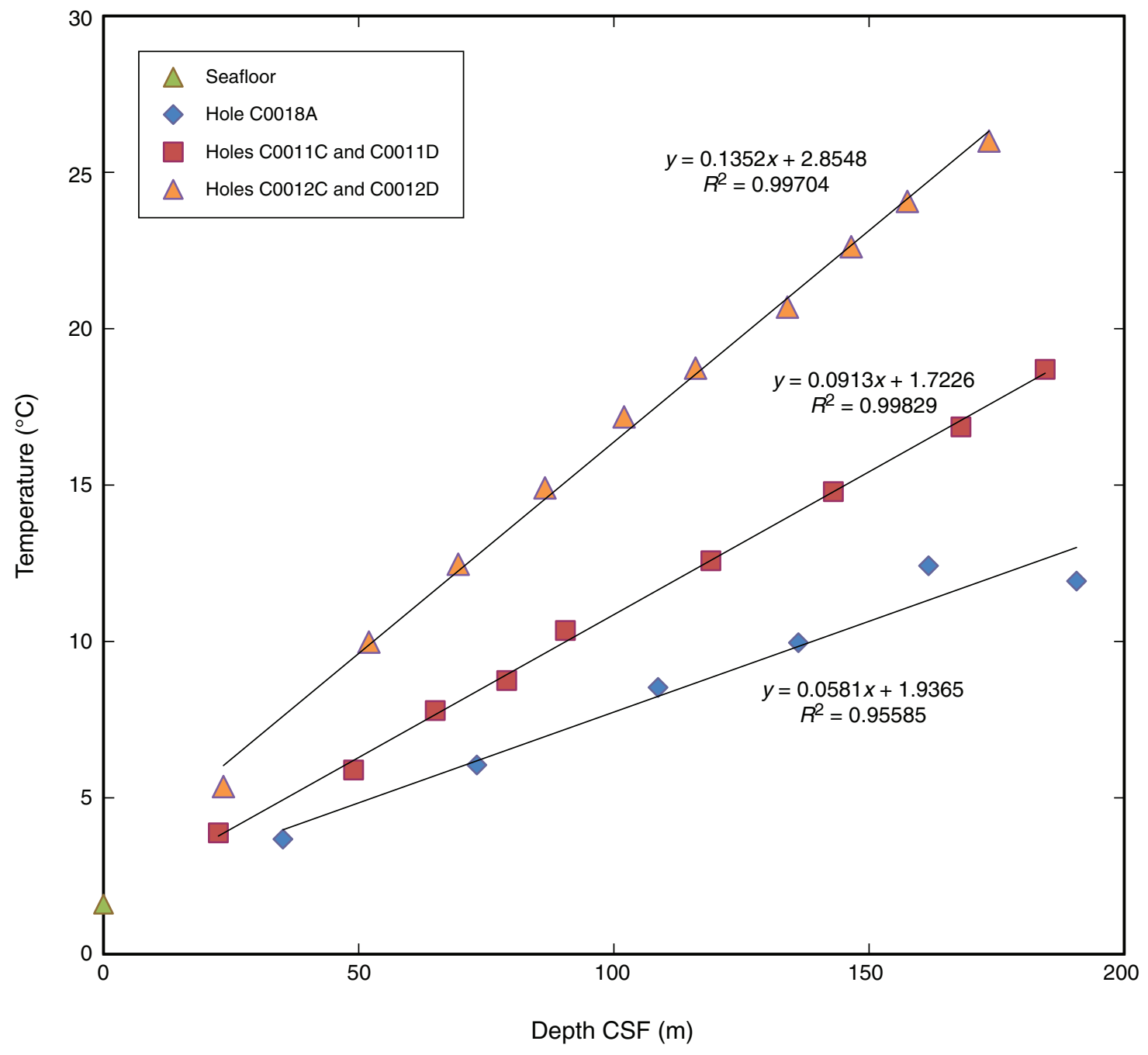


Figure F9. Detailed bathymetric map of Kashinosaki Knoll and Nankai Trough showing location of Sites C0011, C0012, and C0018.

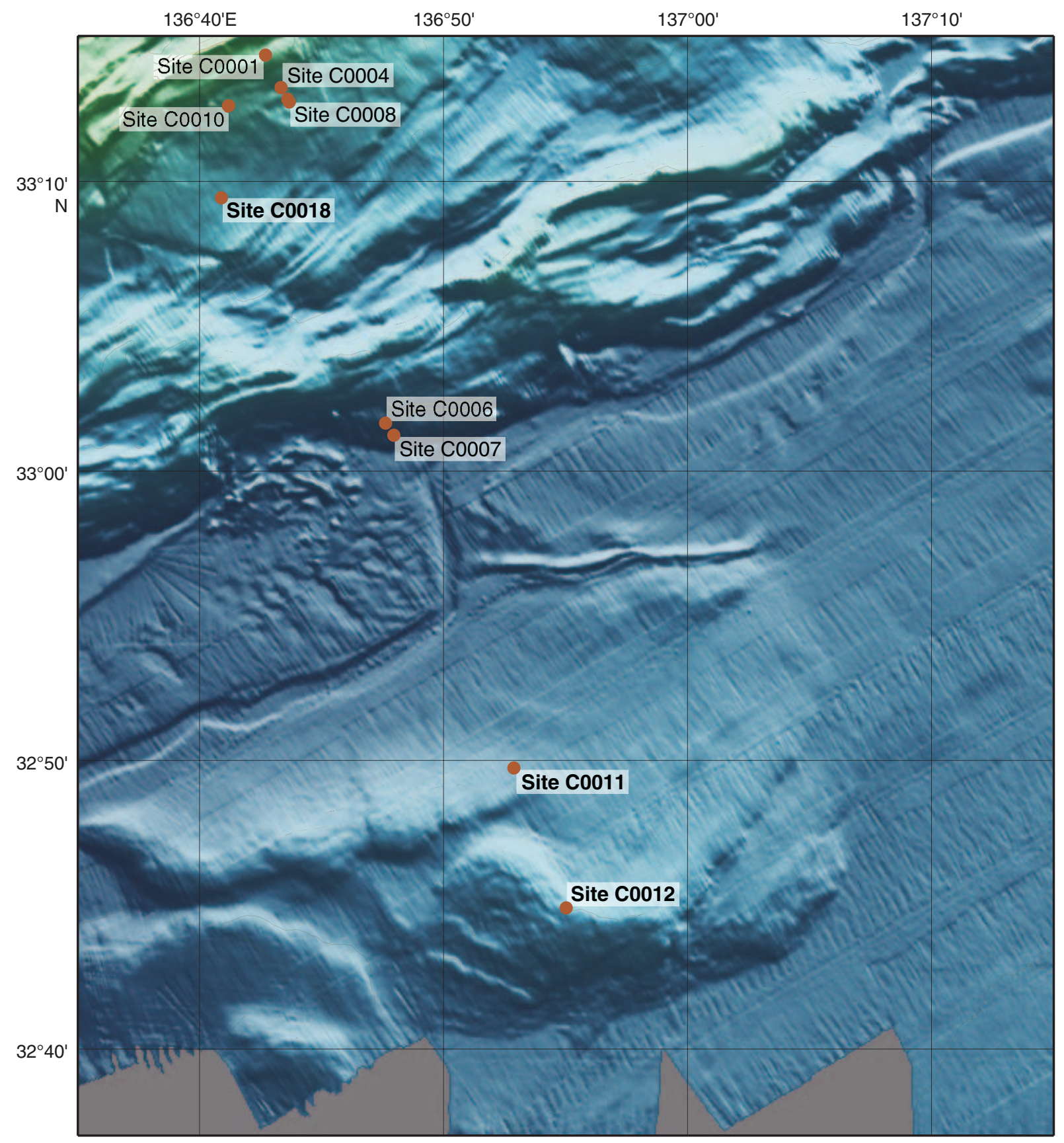


Figure F10. Lithologic columns on seismic background across Kashinosaki Knoll showing Sites C0011 and C0012, using results from Expeditions 333 and 322 (Underwood et al., 2010). VE = vertical exaggeration.

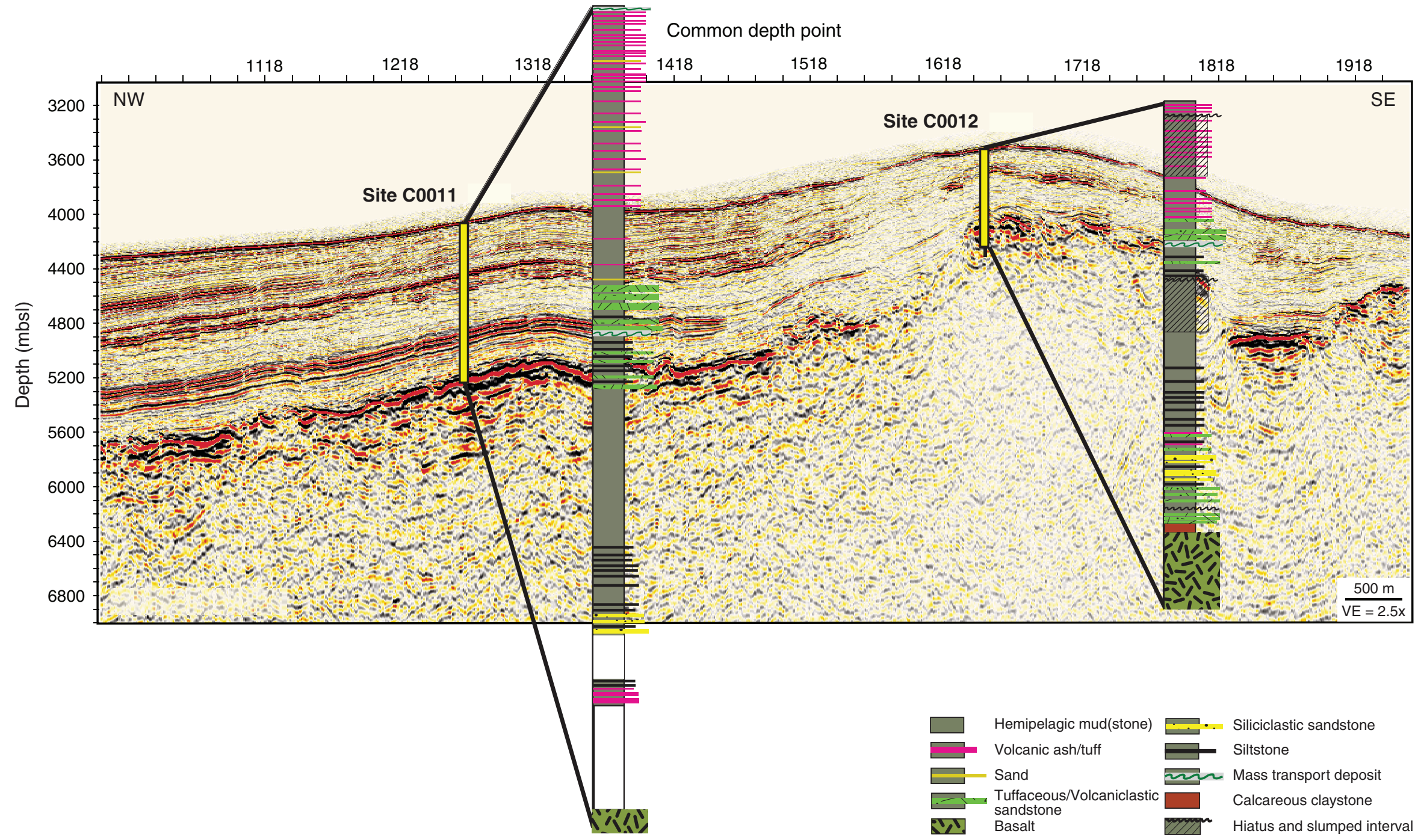


Figure F11. Variations of $\mathrm{SiO}_{2}, \mathrm{Al}_{2} \mathrm{O}_{3}, \mathrm{CaO}, \mathrm{Fe}_{2} \mathrm{O}_{3}, \mathrm{MgO}, \mathrm{Na}_{2} \mathrm{O}$, and $\mathrm{K}_{2} \mathrm{O}$ contents as a function of depth, Site C0011.

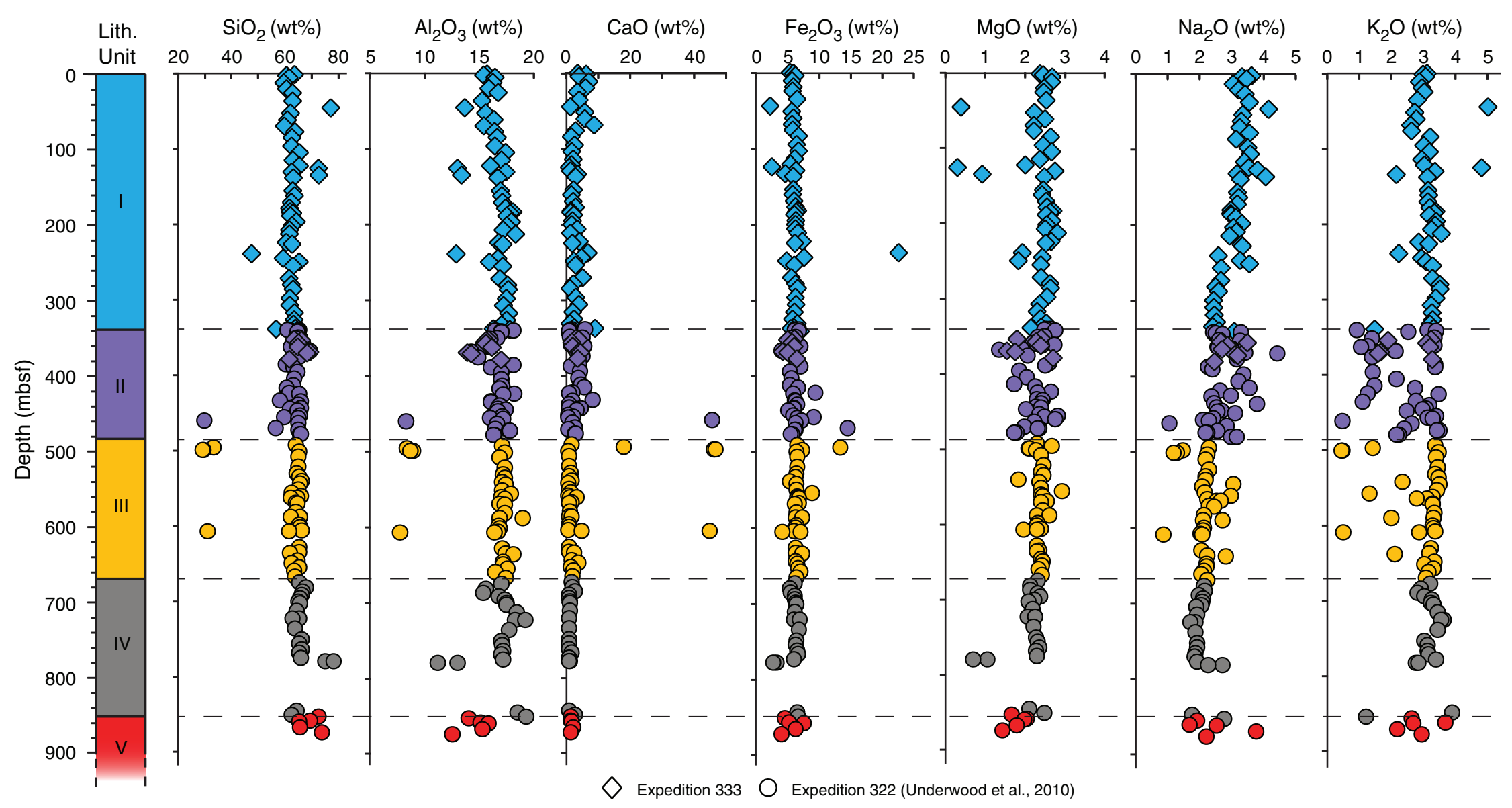




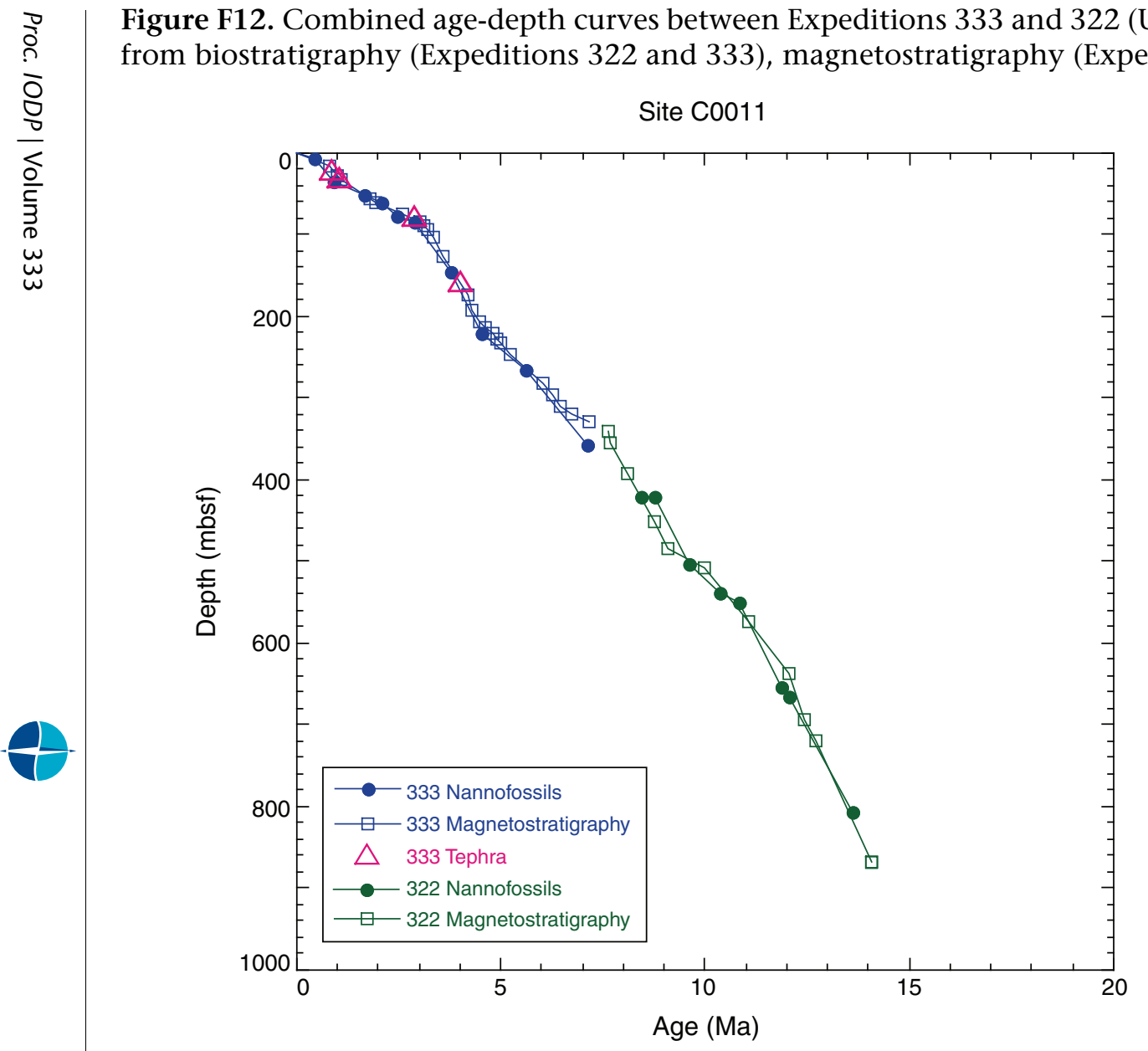

Figure F12. Combined age-depth curves between Expeditions 333 and 322 (Underwood et al., 2010), Sites C0011 and C0012. Age data are derived from biostratigraphy (Expeditions 322 and 333), magnetostratigraphy (Expeditions 322 and 333), and tephra stratigraphy (Expedition 333).

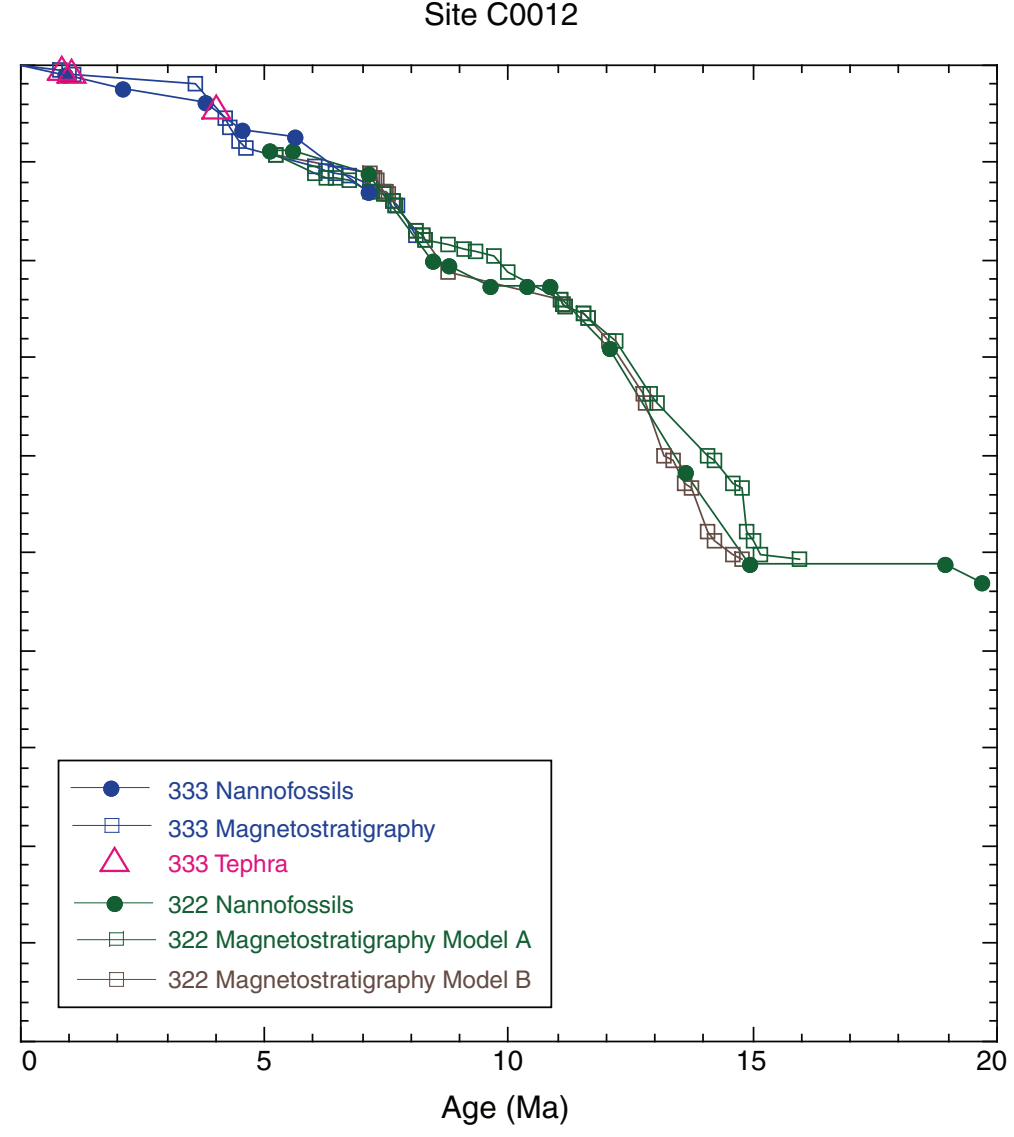


Figure F13. Stratigraphic correlation between Sites C0011 and C0012, based on composite lithology columns and age information from Expeditions 322 and 333. Unit boundary ages taken from integrated age-depth models.

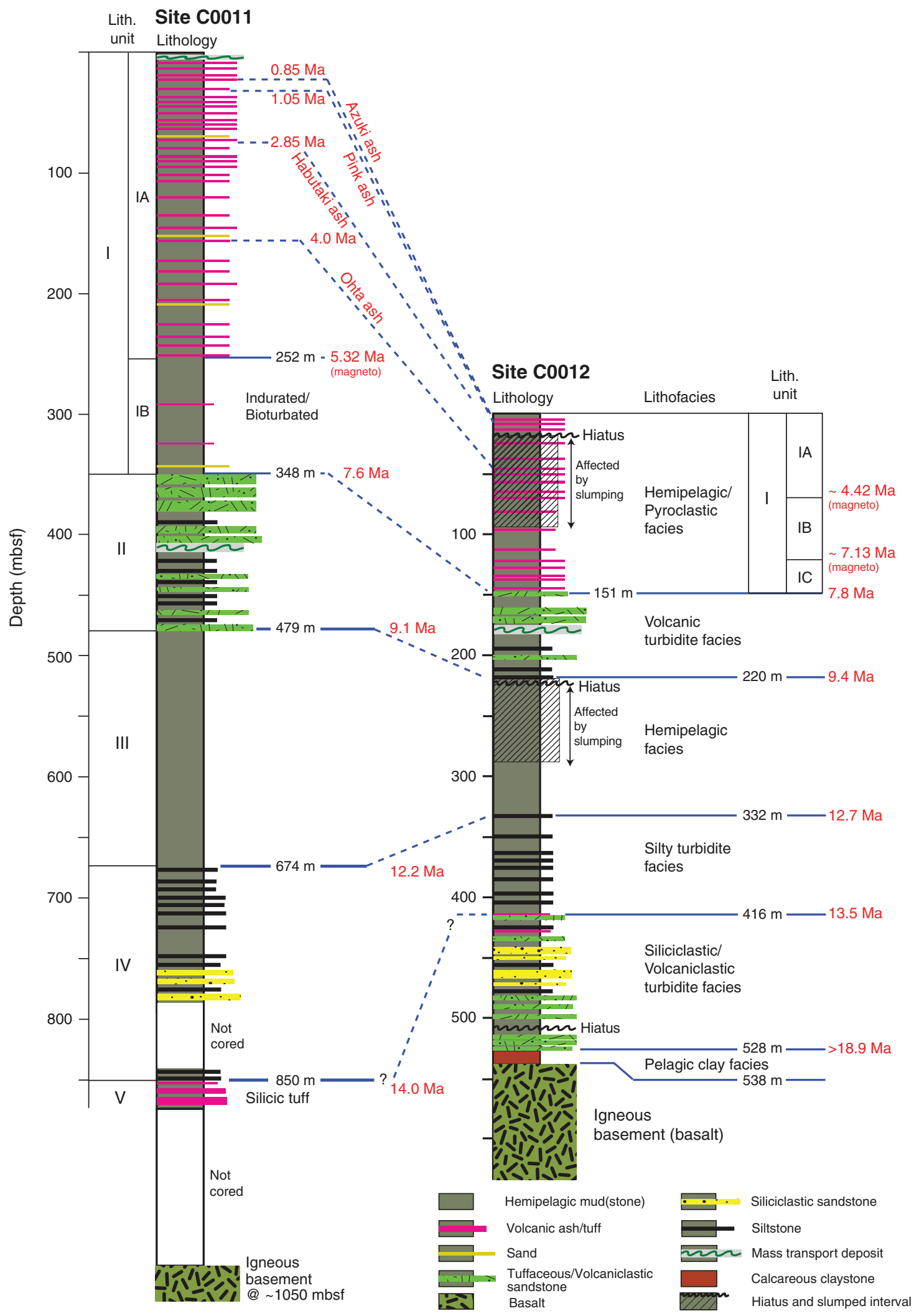


Figure F14. Variations of $\mathrm{SiO}_{2}, \mathrm{Al}_{2} \mathrm{O}_{3}, \mathrm{CaO}, \mathrm{Fe}_{2} \mathrm{O}_{3}, \mathrm{MgO}, \mathrm{Na}_{2} \mathrm{O}$, and $\mathrm{K}_{2} \mathrm{O}$ contents as a function of depth, Site C0012.

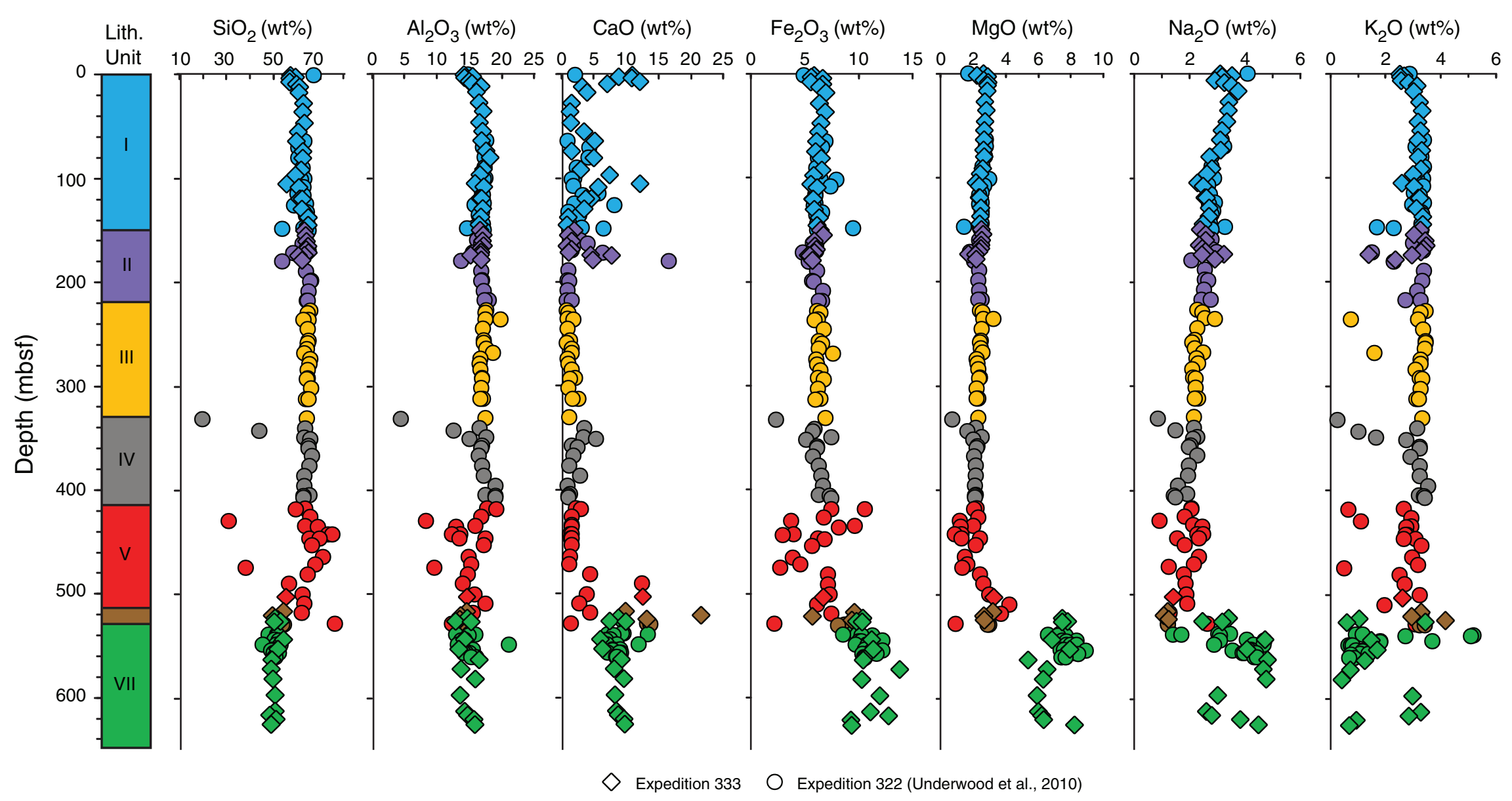


Figure F15. A. Distribution of bedding dip angles and deformation structures with depth, Holes C0012C and C0012D. Lines = boundaries between four zones defined based on dipping angle distribution. B. Equal-area stereographic projection (lower hemisphere) of bedding plane poles above $15 \mathrm{mbsf}$ (Zone 1). C. Equal-area stereographic projection (lower hemisphere) of bedding planes and poles between 15 and 85 mbsf (Zone 2). D. Equalarea stereographic projection (lower hemisphere) of fault planes and poles (all zones).
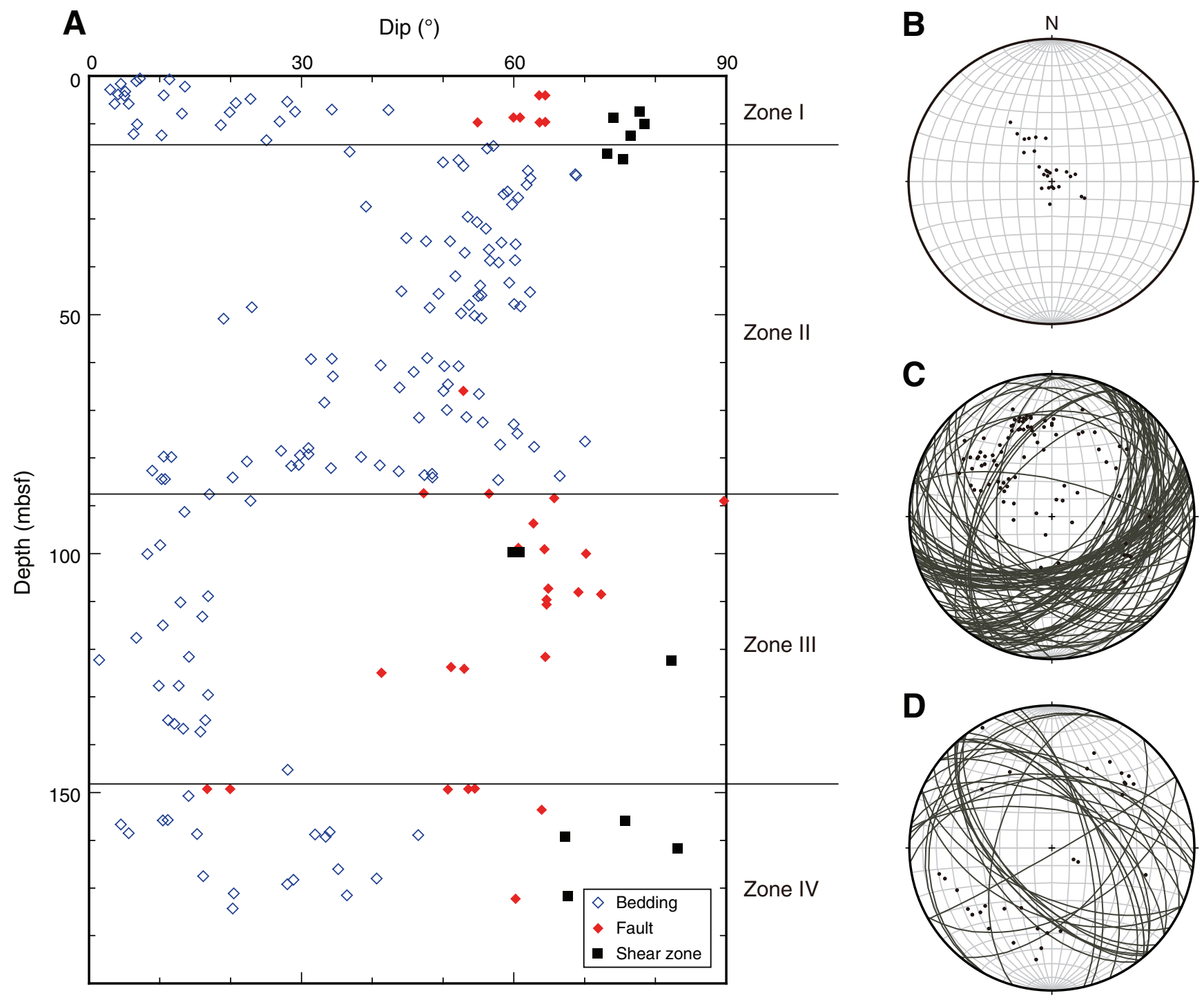
Figure F16. Comparison of porosity data from Site C0011 and C0012 mudstones.

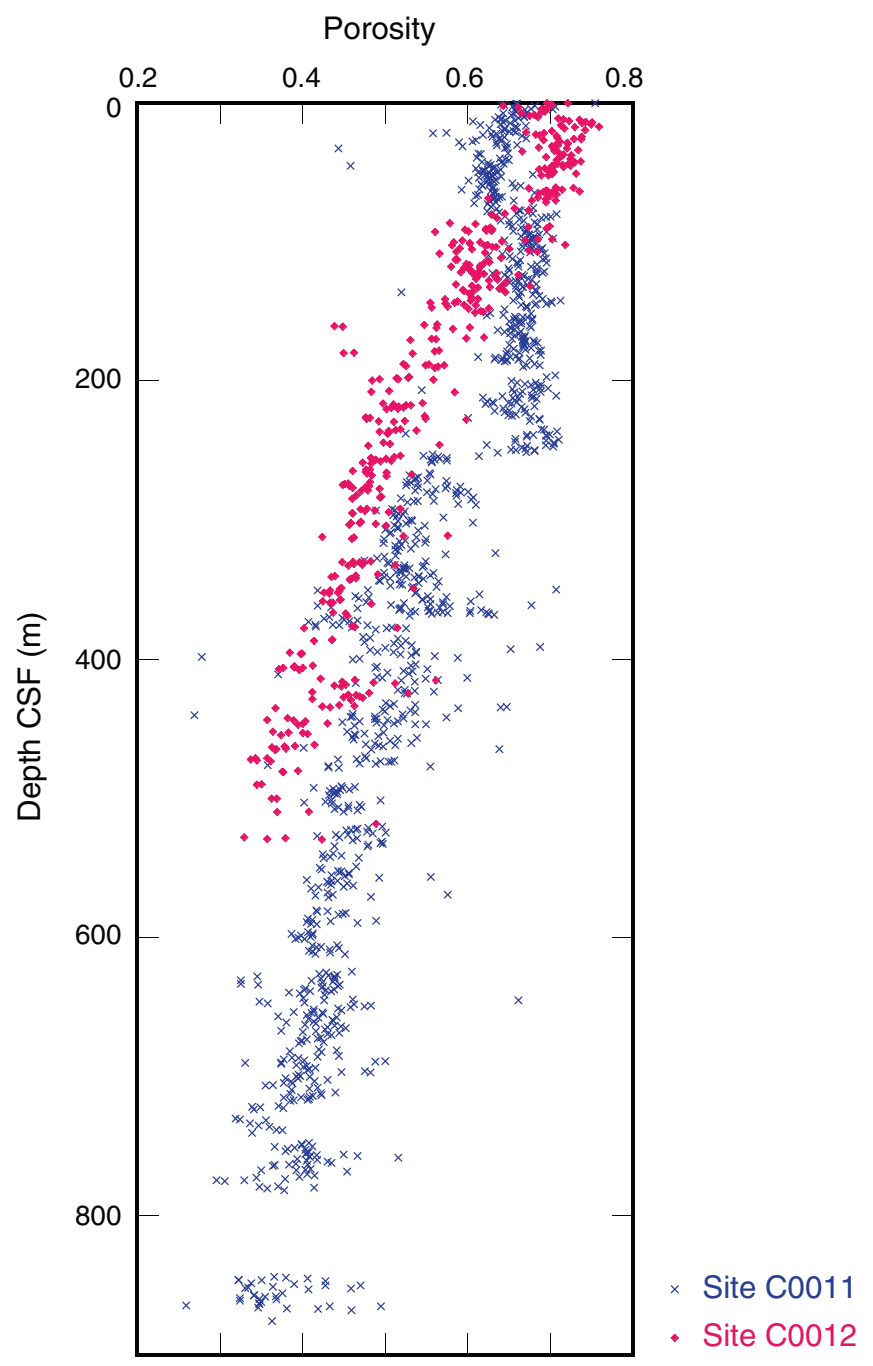


Figure F17. A. $P$-wave velocity in the $z$-direction measured on discrete samples, Holes C0012E, C0012F, and C0012G. B. Vertical plane anisotropy of $P$-wave velocity determined from measurements on discrete samples. Positive is higher velocity in horizontal direction. C. Resistivity in the $Z$ direction measured on discrete samples. D. Vertical plane anisotropy of resistivity determined from measurements on discrete samples. Positive is higher resistivity in horizontal direction.

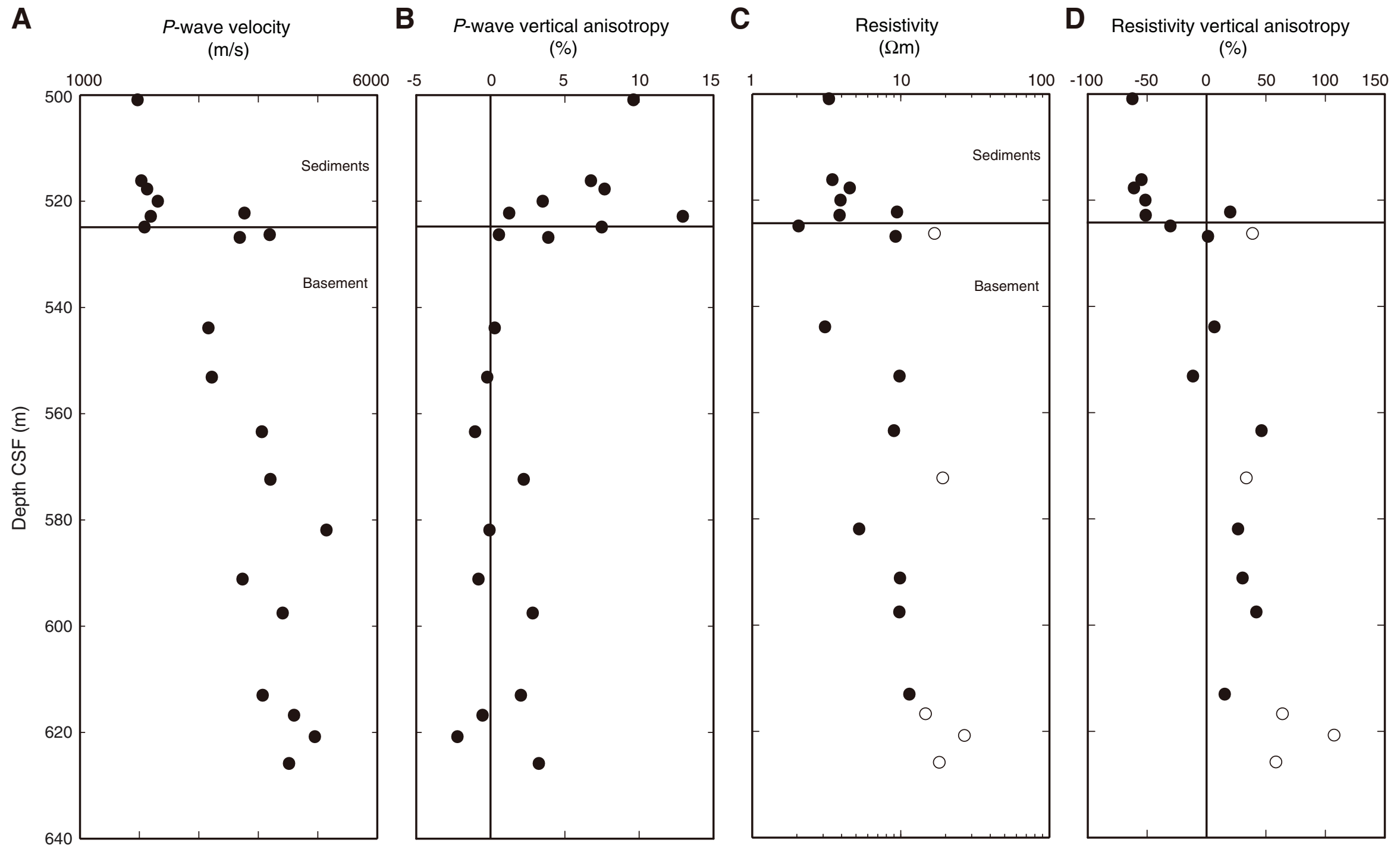




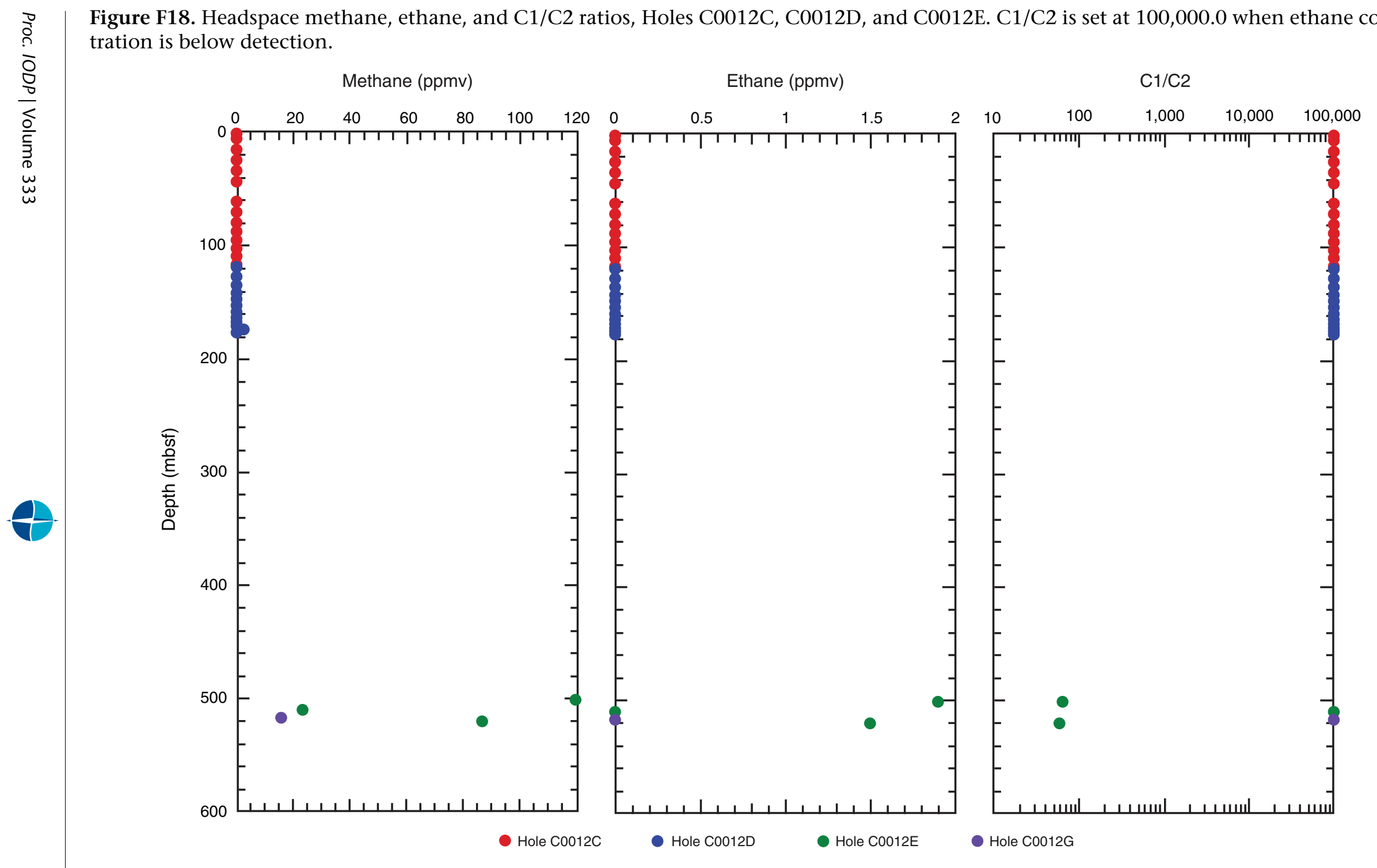


Figure F19. Calcium carbonate $\left(\mathrm{CaCO}_{3}\right)$, total organic carbon (TOC), total nitrogen (TN), atomic ratios of TOC to TN (TOC/TN ${ }_{\mathrm{at}}$ ), and total sulfur (TS) in bulk sediment, Holes C0012C, C0012D, and C0012E.

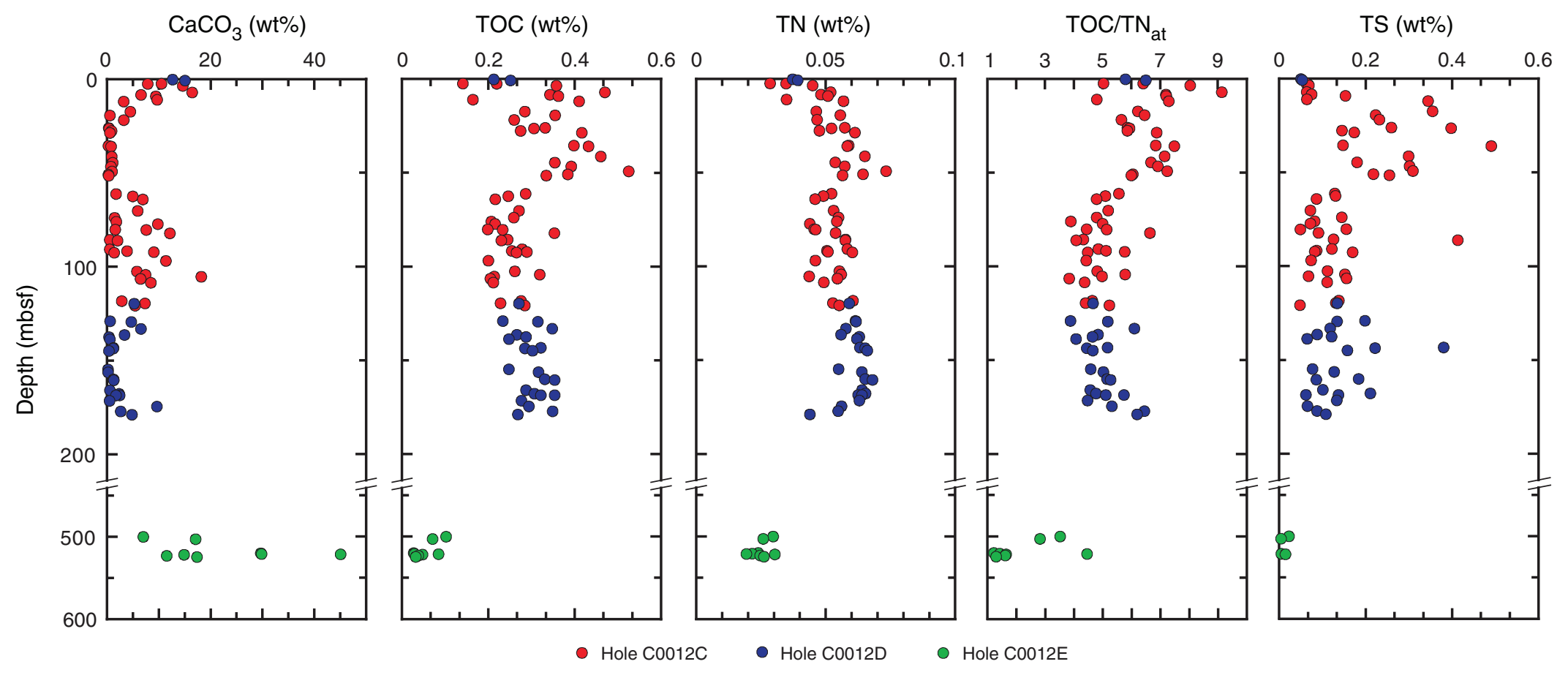

